\title{
OPEN SOURCE SOFTWARE FOUNDATION: \\ COMPANY INVOLVEMENT, GOVERNANCE, AND \\ EFFECTIVENESS
}

by

Zhensheng Xie

A thesis submitted to the Faculty of Graduate Studies and Research in partial fulfillment of the requirements for the degree of Master of Applied Science in Technology Innovation Management

Department of Systems and Computer Engineering, Carleton University

Ottawa, Canada, K1S 5B6

June 2008

OCopyright 2008 Zhensheng Xie 


$\begin{array}{ll}\begin{array}{l}\text { Library and } \\ \text { Archives Canada }\end{array} & \begin{array}{l}\text { Bibliothèque et } \\ \text { Archives Canada }\end{array} \\ \begin{array}{l}\text { Published Heritage } \\ \text { Branch }\end{array} & \begin{array}{l}\text { Direction du } \\ \text { Patrimoine de l'édition }\end{array} \\ \begin{array}{l}\text { 395 Wellington Street } \\ \text { Ottawa ON K1A 0N4 } \\ \text { Canada }\end{array} & \begin{array}{l}\text { 395, rue Wellington } \\ \text { Ottawa ON K1A 0N4 } \\ \text { Canada }\end{array}\end{array}$

Your file Votre référence ISBN: 978-0-494-44063-6

Our file Notre référence

ISBN: 978-0-494-44063-6

NOTICE:

The author has granted a nonexclusive license allowing Library and Archives Canada to reproduce, publish, archive, preserve, conserve, communicate to the public by telecommunication or on the Internet, loan, distribute and sell theses worldwide, for commercial or noncommercial purposes, in microform, paper, electronic and/or any other formats.

The author retains copyright ownership and moral rights in this thesis. Neither the thesis nor substantial extracts from it may be printed or otherwise reproduced without the author's permission.
AVIS:

L'auteur a accordé une licence non exclusive permettant à la Bibliothèque et Archives Canada de reproduire, publier, archiver, sauvegarder, conserver, transmettre au public par télécommunication ou par l'Internet, prêter, distribuer et vendre des thèses partout dans le monde, à des fins commerciales ou autres, sur support microforme, papier, électronique et/ou autres formats.

L'auteur conserve la propriété du droit d'auteur et des droits moraux qui protège cette thèse. $\mathrm{Ni}$ la thèse ni des extraits substantiels de celle-ci ne doivent être imprimés ou autrement reproduits sans son autorisation.
In compliance with the Canadian Privacy Act some supporting forms may have been removed from this thesis.

While these forms may be included in the document page count, their removal does not represent any loss of content from the thesis.
Conformément à la loi canadienne sur la protection de la vie privée, quelques formulaires secondaires ont été enlevés de cette thèse.

Bien que ces formulaires aient inclus dans la pagination, il n'y aura aucun contenu manquant.

\section{Canada}




\section{ABSTRACT}

This exploratory research compiles data from six foundations (i.e., Apache Software Foundation, Eclipse Foundation, GNOME Foundation, Plone Foundation, Python Software Foundation, and Software in the Public Interest) and uses it to examine the relationship among company involvement, governance, and effectiveness of open source software foundations (OSSFs). This research: (i) organizes OSSFs into three types: Merit, Merit-Dominated, and Sponsor-Dominated based on the rights of merit and sponsor members; (ii) uses the presence of open source celebrities on the OSSF's Board of Directors as a measure of prestige; (iii) identifies practices and compositions of OSSF's Board of Directors; (iv) develops a model on how company involvement and governance affect OSSF effectiveness; and (v) provides observations useful to executive directors of OSSFs, companies' top management teams who anchor business models around open source software projects, and academics who study nonprofit organizations. 


\section{ACKNOWLEDGEMENT}

I thank my thesis supervisor Professor Tony Bailetti. This research could have not been completed without his insightful suggestions, tireless guidance, and encouragement.

I wish to express my appreciation to my wife and parents for their unconditional support and continuous encouragement. With their love and concern, the research process was enjoyable. 


\section{TABLE OF CONTENTS}

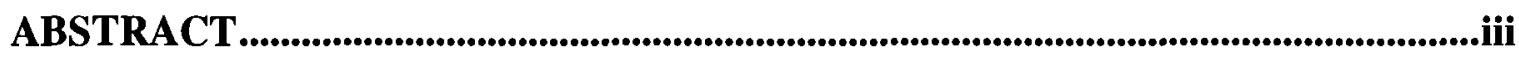

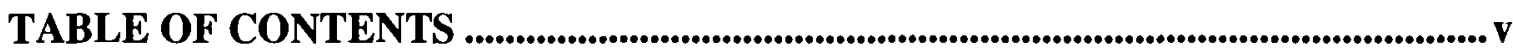

LIST OF TABLES ..............................................................................................................iii

LIST OF FIGURES .........................................................................................................................

LIST OF APPENDICES .......................................................................................................

1 INTRODUCTION.............................................................................................................. 1

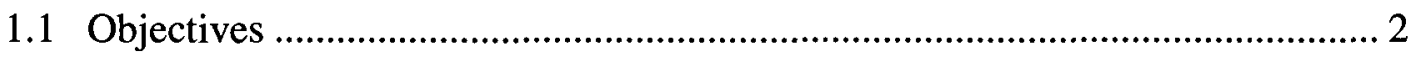

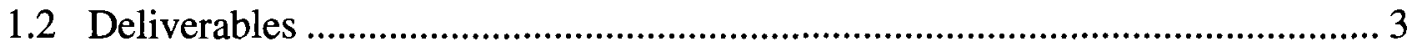

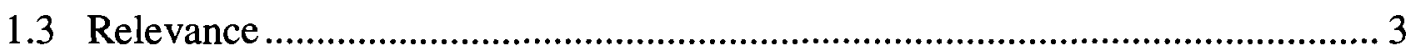

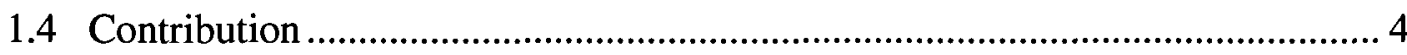

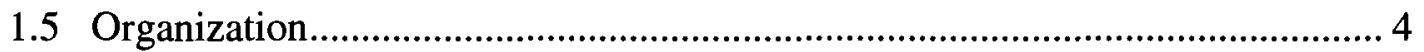

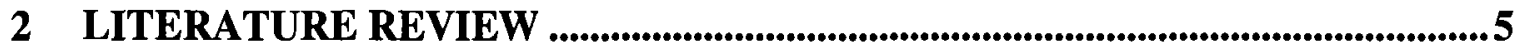

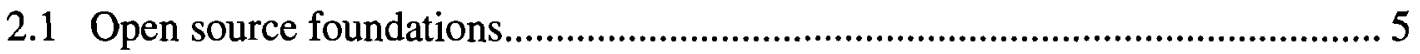

2.2 NPO governance and governance model ............................................................ 6

2.3 Nonprofit organizational effectiveness .............................................................. 9

2.4 Relationship between governance and effectiveness ......................................... 12

2.4.1 NPO governance structures.................................................................. 13

2.4.2 BOD's practice .................................................................................... 14

2.4.3 BOD composition .......................................................................... 18

2.5 Open source software project and community governance ............................... 18

2.5.1 Why open source communities need foundations .................................. 18

2.5.2 OSSF governance and effectiveness ...................................................... 18

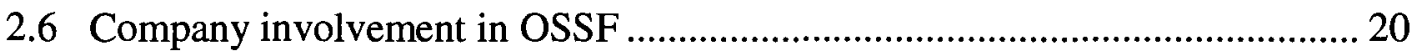

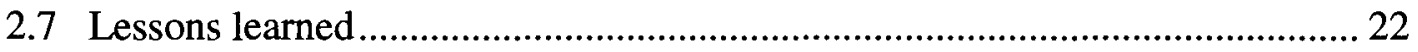

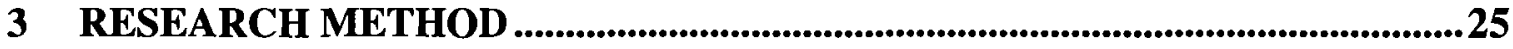

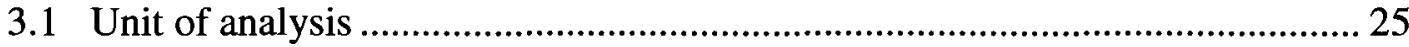

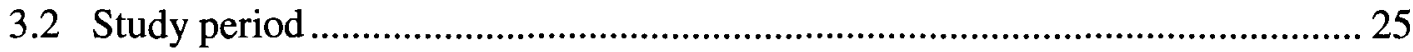

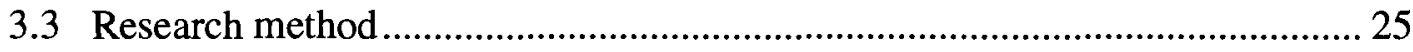

3.3.1 Set criteria for sample selection ......................................................... 26 
3.3.2 Assemble list of open source software foundations and select sample 27

3.3.3 Identify constructs and dimensions from the literature review............ 29

3.3.4 Identify and collect data on constructs............................................. 31

3.3.5 Collect data for identified metrics................................................... 32

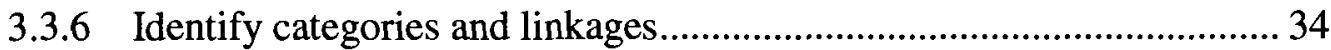

3.3.7 Identify BOD activity breakdown, and links .................................. 34

3.3.8 Develop model and propositions anchored around the model.............. 35

3.3.9 Answer research questions................................................................ 36

3.3.10 Link results to the literature and generate observations...................... 36

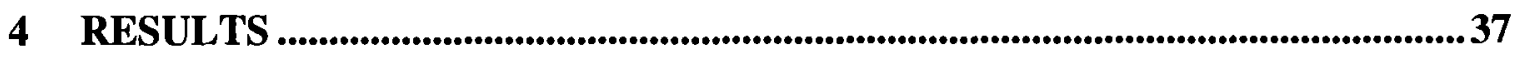

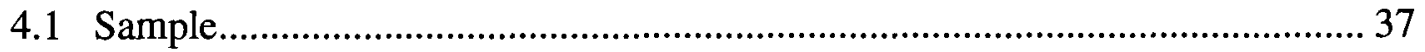

4.2 Dimensions and metrics identified from examining the data ........................ 41

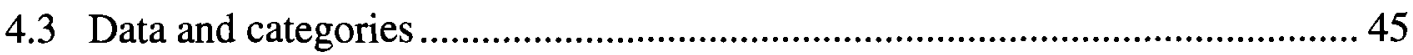

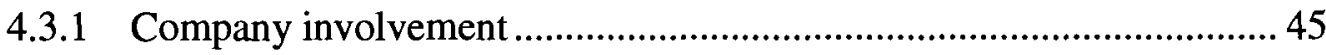

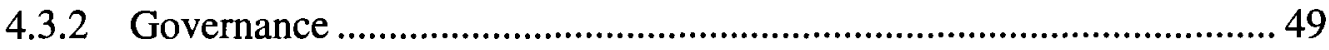

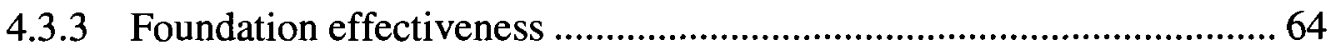

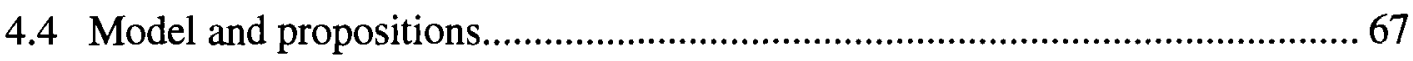

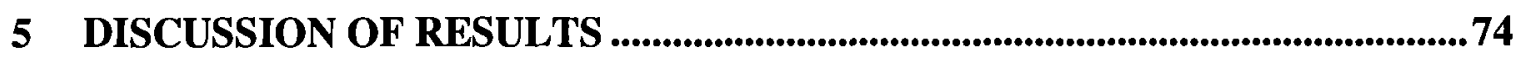

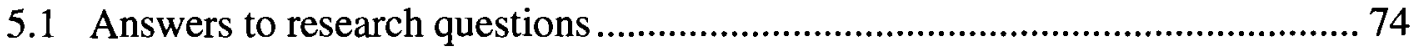

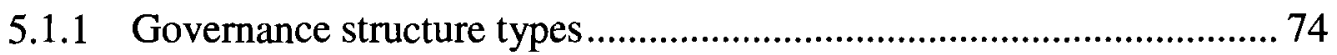

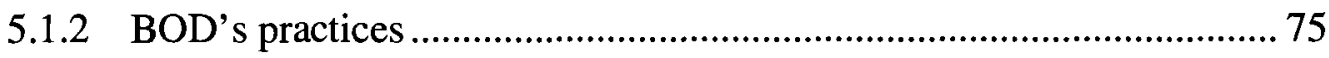

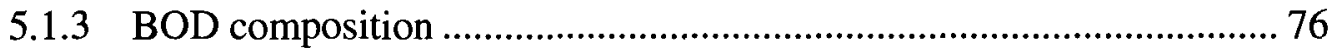

5.2 Model on how company involvement and governance affect OSSF

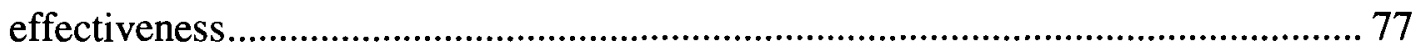

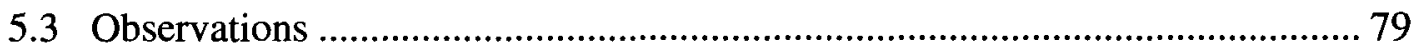

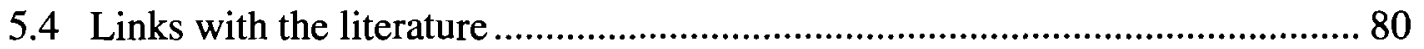

6 CONCLUSIONS, LIMITATIONS, AND FUTURE RESEARCH .....................82

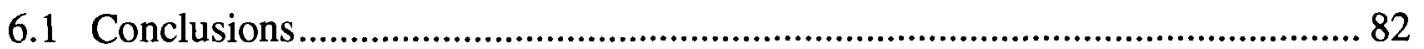

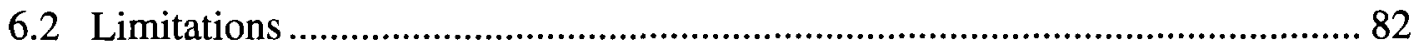

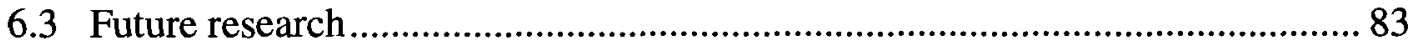

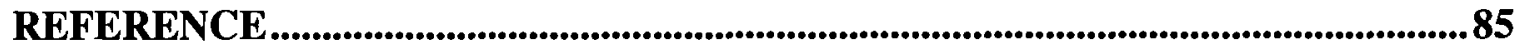




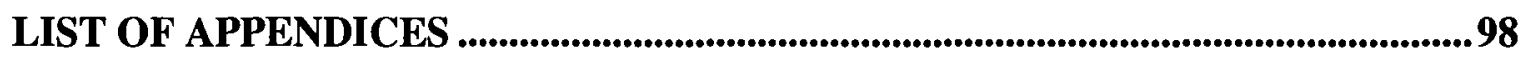




\section{LIST OF TABLES}

Table 1: Dimensions for nonprofit effectiveness drawn from the literature review. 12

Table 2: Aspects and dimensions for governance drawn from the literature review 13

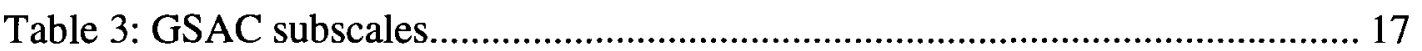

Table 4: Constructs and dimensions for company involvement drawn from the

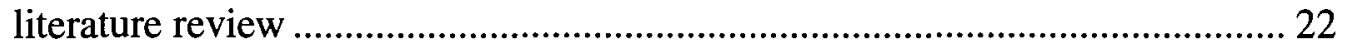

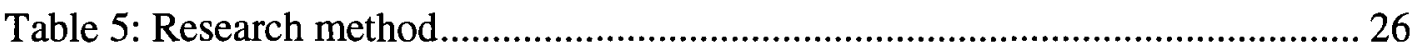

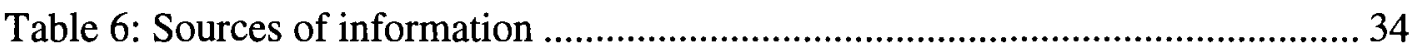

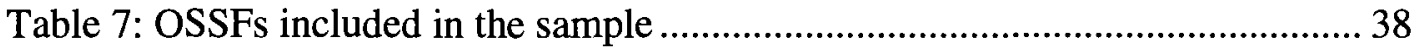

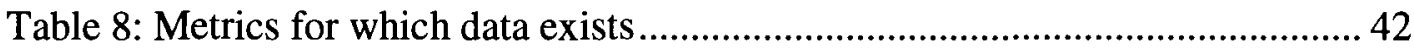

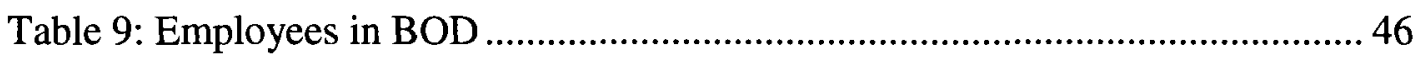

Table 10: Employees in BOD who are part of TMT $^{*}$...........................................49

Table 11: Participation in decision making ........................................................ 51

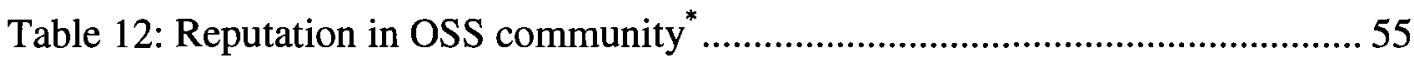

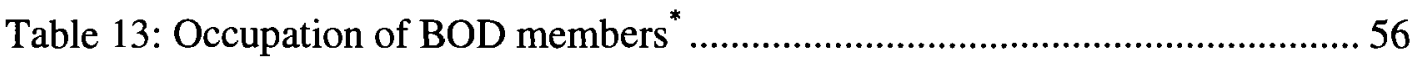

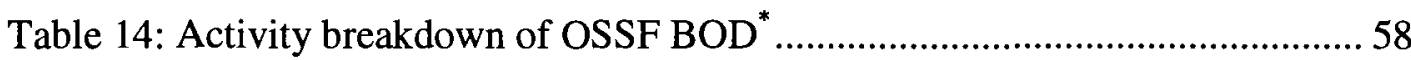

Table 15: Activity breakdown of OSSF BOD excluding the project governance

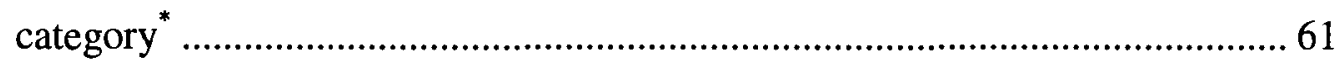

Table 16: Method used to carry out governance activities .................................. 62

Table 17: Difference in OSSF's primary policies and guidelines ..........................6 63

Table 18: Project effectiveness: number of projects in OSSFs.............................. 65

Table 19: Community effectiveness: number of foundation members (merit and

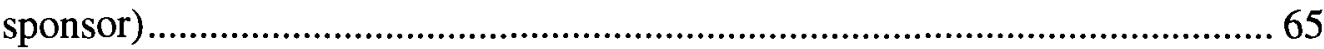

Table 20: Resource effectiveness: financial effectiveness...................................66

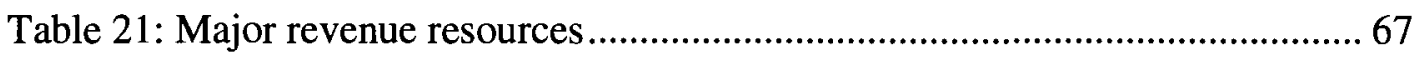




\section{LIST OF FIGURES}

Figure 1: Relationship among company involvement, governance and effectiveness drawn from the literature review .................................................................. 24

Figure 2: Proportion of company employees in BOD ............................................... 47

Figure 3: Proportion of employees in BOD from companies that do not depend on OSSF's projects for significant portion of revenue

Figure 4: Extent to which a sponsor member can participate in OSSF decision making.

Figure 5: Proportion of members of BOD who are celebrities in the OSS community

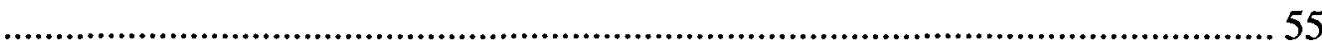

Figure 6: Proportion of members of BOD who are engineers/scientists

Figure 7: Proportion of BOD's efforts dedicated to strategic planning and common vision development.

Figure 8: Extent to which a committee of the BOD has power over the timing and content of software releases 64

Figure 9: Revenue of OSSFs. 66

Figure 10: Model for how company involvement and governance affect OSSF effectiveness. 68 


\section{LIST OF APPENDICES}

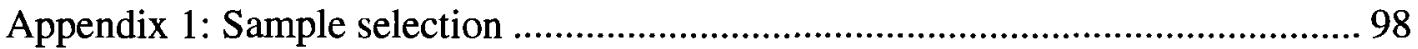

Appendix 2: Dimensions and metrics drawn from the data.................................... 100

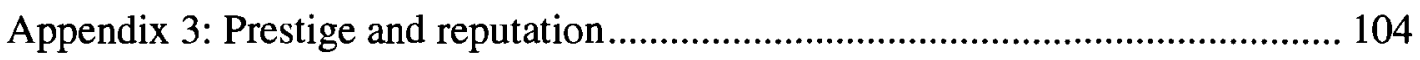

Appendix 4: Project effectiveness ..................................................................... 108

Appendix 5: Community effectiveness............................................................... 110

Appendix 6: Resources effectiveness …………………….................................. 112 


\section{INTRODUCTION}

Communities that develop open source software are virtual entities on the Internet and not legal entities. Open source software foundations (OSSF) are established as the legal entities of open source communities because the communities want to protect their intellectual property and carry out contractual arrangements. Foundations help communities attain their long-term goals, hold community assets, provide resources to communities, and balance the interests among different stakeholders (O'Mahony, 2003b; Balser \& McClusky, 2005).

Research on OSSF is inadequate (O'Mahony, 2003b). There is a need to assess OSSF effectiveness. Company involvement and governance are two factors deemed to affect the effectiveness of nonprofit organizations (Green \& Griesinger, 1996; Smith \& Shen, 1996; O’Mahony, 2003b).

For the purpose of this research, an OSSF must have at least one active software project. A software project is considered to be active if individuals are contributing to a new software release. OSSF effectiveness refers to the ability of a foundation to utilize resources to achieve its goals and missions (Forbes, 1998). Company involvement in an OSSF refers to when the company invests resources in an OSSF and influences the mission, primary organizational activities, and relationships of the OSSF.

A company may directly influence an OSSF by having its employees hold seats in the Board of Directors (BOD) and other governance groups of the OSSF. In this instance, the 
company directly affects the decision making processes. A company indirectly influence decisions made by the members of an OSSF. In this instance, the company provides resources to affect a decision (Pfeffer and Salancik, 1978).

Governance refers to the overall processes and structures used to direct and manage an organization's operations and activities. Most of the OSSFs are membership based nonprofit organizations. They "serve a membership and give that membership democratic rights of governance" (Spear, 2004). The BOD of a membership based nonprofit is the major actor responsible for governance (Schnurbein, 2006). Individuals who sit on the BOD are elected by the members of an OSSF. A member can be a merit member or a sponsor member. An individual becomes a merit member after being recognized as making non-trivial contributions to the foundation. A sponsor member is a company which donates resources to an OSSF and in return is admitted as member of foundation because of the donation. Thus, individuals are merit members while organizations are sponsor members. Typically, employees of organizations represent sponsor members.

\subsection{Objectives}

The objective of this research is to examine the relationship among company involvement, governance, and OSSF effectiveness by answering the following four questions:

(i) What are the different types of governance structures of OSSFs?

(ii) What are the practices of the BOD of OSSFs?

(iii) What is the composition of the BOD of OSSFs?

(iv) How do company involvement and governance affect OSSF effectiveness? 


\subsection{Deliverables}

The deliverables of this research are:

(i) Types of OSSFs' governance structures

(ii) Practices and compositions of BOD of OSSFs

(iii) A model for the relationship among company involvement, governance, and OSSF effectiveness

(iv) Observations on company involvement, governance, and OSSF effectiveness useful to executive directors of OSSFs, companies' top management teams, and academics.

\subsection{Relevance}

This research is relevant to executive directors of OSSFs, companies' top management teams, and academics.

Executive directors of OSSFs can use the model developed in this thesis as a guide to improve the effectiveness of their organizations.

This research will be useful to companies' top management teams who build business models around open source software (OSS) projects. They can incorporate the findings of this research into strategies that seek to align the communities' objectives with their own.

Academics will be interested in this research because it provides new examples of 
governance structures of nonprofit organizations responsible for advancing open source software.

\subsection{Contribution}

This research makes at least three contributions. First, the researcher built a bottom up model using publicly available data on company involvement, governance, and effectiveness. This research discovered associations which were not reported in the literature previously.

Second, this research successfully identified different types of governance structures and the types of contributions each structure attracts. The result of this research can be used to segment contributors to OSSF.

Third, this research fills gaps in the open source and nonprofit literature stream. Little is known about OSSF governance, company involvement, and OSSF effectiveness.

\subsection{Organization}

The thesis is organized into six chapters. The first chapter is the introduction. The second chapter reviews the literature and identifies the lessons learned from reviewing it. The third chapter describes the research method. The fourth chapter presents the results. The fifth chapter discusses the results. The sixth chapter provides conclusions, describes the limitations of the research, and identifies opportunities for future research. 


\section{LITERATURE REVIEW}

An OSSF is a non-profit organization (NPO). This thesis draws extensively on the large scholarly literature on NPO governance and effectiveness for constructs, relationships, and metrics. Very few researchers have examined OSSFs.

This chapter is organized into seven sections. Section 2.1 reviews the literature on OSSF. Section 2.2 reviews the literature on non-profit organization governance and governance models. Section 2.3 reviews the literature on non-profit organizational effectiveness. Section 2.4 reviews the literature on relationship between governance and effectiveness for non-profit organizations. Section 2.5 reviews the literature on open source software project and community governance. Section 2.6 reviews the literature on company involvement in OSSF. Section 2.7 presents the lessons learned from the literature review.

\subsection{Open source foundations}

The missions of open source projects and communities are to advance public interests. When they incorporate as OSSF they seek to gain financial advantages from donations and tax exemptions (O’Mahony, 2003a).

The primary objective of a NPO is to "support or to actively engage in activities of public or private interest without any commercial or monetary profit purposes" (Alvarado, 2000). Under the law, an NPO is a corporation that can handle business dealings, sign contracts, and own property as any other individual or for-profit corporation may do. NPOs differ from for-profits in terms of taxes and governance (Green \& Griesinger, 1996). 
NPOs' governance structures preclude private financial gain (Wolf, 1984). OSSFs in the United States are registered under tax-exempt 501(c)(3) or 501(c)(6). 501(c)(6) is reserved for "Business Leagues and groups such as Chambers of Commerce", which is a form of business network ${ }^{1}$ in favor of pursuing members' own business interests. 501(c)(3) organizations provide public benefits ${ }^{2}$. Most OSSFs registered in the United States are 501(c)(3) non-profit organizations (O’Mahony, 2003b).

Both 501(c)(3) and 501(c)(6) non-profit organizations are exempt from most federal income taxes. OSSFs registered outside of the United States may have similar benefits.

Open source software is a rather new phenomena relative to proprietary software. From a legal perspective, an OSSF is still a legacy NPO.

\subsection{NPO governance and governance model}

In nonprofit organizations, the executive is responsible for the effectiveness and performance of the organization. The NPO addresses the interests of its multiple stakeholders -- funders, internal and external groups, and the public (McClusky, 2002; Burlingame, 2004; Spear, 2004).

Various perspectives on governance exist throughout the literature. It is common to

\footnotetext{
1 IRS Publication 557

${ }^{2}$ IRS Publication 557
} 
consider governance to be tightly connected to the BOD (Dayton, 1987; Duca, 1996; Green \& Griesinger, 1996).

Dayton (1987) and Carver $(1996,2001)$ define governance as the activities carried out by the BOD. McClusky (2002), however, claims that this definition is unsatisfactory, both in theory and practice

Hult and Walcott (1990) define four major aspects of governance: "mission, primary organizational activities, decision-making participants, and environmental relations”. Interactions among different organizational actors and stakeholders are highlighted. McClusky (2002) drew ideas from Parson (1991) and proposed that governance could be viewed as the function of NPO at the institutional level. He also argues that governance should not only include the traditional elements of governance, but also what might be considered combined governance and executive responsibilities. To McClusky (2002), governance should include rights and responsibilities such as fiduciary responsibility as stewards or trustees, BOD policy-making, and long-range goal/mission setting, strategic planning, formulating and directing strategy, environment and external relations management and directing financial resource development.

Houle (1989) and Carver $(1996,2001)$ proposed two of the most influential prescriptive governance models (Duca, 1996; McClusky, 2002). Houle (1989) listed eleven functions of the governing BOD and described the "shared responsibility" between the BOD and the executive staff. Organized staffs are assumed to have important governance, 
management roles in these governance functions. Carver's $(1996,2001)$ “policy governance" model argues that the responsibilities of the BOD and the executive staff are distinct. The BOD should always do "governance and policy-making", while the staff should perform "administration and management".

Noticing the roles played by advisory groups in nonprofit governance, Bradshaw et al. (1998) propose a new governance model which highlights the functions of advisory groups in governance. In their model, the BOD, executive staff, and advisory groups are all participants in governance activities. There are no clear boundaries between each party, however. Each party shares governance roles defined by Hult and Walcott (1990). Advisory groups enhance organizational governance capacity by providing "additional programmatic, service delivery and accountability assistance” (Bradshaw et al., 1998).

Widmer and Houchin (1997) found that membership bodies and other entities have significant governance responsibilities in national federated organizations.

Alexander and Weiner (1988) examined the suitability of the corporate governance model for NPOs. Hodgkin (1993) argued against adopting the corporate governance model by noting it was "a dangerous error" for nonprofits.

Bradshaw et al. (1998) advanced a governance model as an emergent cellular model and hybrid model. The cellular model is "characterized by continuous, organic innovation. This model is evolving from the network form which allows for flexibility and 
responsiveness to information. Cellular organizations are made up of cells (self-managing teams, autonomous business units, operational partners, etc.) that can operate alone but that can interact with other cells to produce a more potent and competent organizational mechanism as well". The hybrid model is a combination of four governance models: policy governance model, constituent/representative board model, corporate board model, and emergent cellular model.

Schnurbein (2006), one of the few researchers who has examined membership based non-profits, proposed that in membership based nonprofits (especially in trade associations and unions) the BOD plays a central role in governance. He argues that the roles of other actors are defined by their relations to the BOD. The roles and groups that dominate a governance structure include: BOD-member, BOD-executive, BOD-environment, and member-executive relations. Members of the BOD are elected by members of the nonprofits to ensure the interests of the members can be realized.

The academic literature defines governance in a variety of ways. This leads to confusion. The boundary between governance and management varies. However, throughout the literature the BOD is always the core actor in governance, and receives most of the interests from scholars and practitioners.

\subsection{Nonprofit organizational effectiveness}

Organizational effectiveness is a useful but problematic concept. Effectiveness is a tool for evaluating and enhancing the work of organizations (Forbes, 1998; Taylor \& 
Sumariwalla, 1993). However, this concept can mean different things to different people, and there are various ways to measure organizational effectiveness (Kanter \& Summers, 1987; Herman 1990). At least three of approaches for assessing nonprofit effectiveness exist and there is little agreement on which measures best capture the nature of nonprofit effectiveness (Forbes, 1998).

Researchers have based their work on three major approaches: (i) goal attainment, (ii) system resource; and (iii) multiple constituency or social constructivism. The goal attainment approach focuses on the extent to which a NPO fulfils its goals and missions. The goal-attainment approach is based on the assumption that organizations' goals are identifiable and unambiguous. This approach defined effectiveness as the extent to which organizations successes in meeting their goals (Glisson \& Martin, 1980; Forbes, 1998).

The system resource approach emphasizes organizational resource procurement. It defines effectiveness as viability or survival. It assesses the ability of organizations to exploit resources from their environments to sustain their goals. This approach is useful in a variety of studies of social services organizations because of the substantial dependence of these organizations on outside sources of funding, and voluntarism (Green \& Griesinger, 1996; Forbes, 1998; Provan, 1980; Pfeffer, 1973; Glisson \& Martin, 1980).

To assess NPO performance, approaches based on goal-attainment and system resource can utilize quantitative data such as that found in annul reports and operational statements (Forbes, 1998). However, this data is not easy to obtain (Cameron \& Whetten, 1983), 
especially when the research targets are the medium and small NPOs which typically lack accounts and records and whose goals often are semiformal and diversified (Smith \& Shen, 1996).

The multiple constituency or social constructivism approach associates effectiveness with the reported opinions of key persons, such as clients, other constituents, or service professionals (Herman, 1990; Herman et al., 1991; Herman \& Renz, 1997, 2000; Taylor et al., 1991; Smith \& Shen, 1996; Forbes, 1998; Schmid, 2002). The social constructivist perspective views an organization as being more effective if it can better satisfy the interests of multiple constituencies within and around it (Schmid, 2002). Reputational assessments are often used in this approach to organizational effectiveness (Schmid, 2002). Effectiveness is assessed based on the survey or self-reports from stakeholders of the organization. The logic behind this approach is that an organization should satisfy individuals, groups and other entities supporting its survival and growth. This is especially critical for NPOs, which gain resources mainly from donation or supporting from their stakeholders (Schmid, 2002).

Cameron (1986), Bies and Cowles (2002) have expanded the number of approaches to conceptualize NPO performance. They have included models that focus on internal processes, legitimacy, fault-driven, and high-performing systems models.

Table 1 shows the dimensions for NPO effectiveness drawn from the literature review organized by approach. 
Table 1: Dimensions for nonprofit effectiveness drawn from the literature review

\begin{tabular}{|l|l|}
\hline Approach & Dimension \\
\hline Goal attainment & Productivity (Glisson \& Martin, 1980) \\
\hline \multirow{2}{*}{ System resources } & $\begin{array}{l}\text { Financial resources (Provan, 1980; Pfeffer, 1973; } \\
\text { Glisson \& Martin, 1980; Green \& Griesinger, 1996) }\end{array}$ \\
\cline { 2 - 2 } & Other resources (Bradshaw et al., 1992) \\
\hline $\begin{array}{l}\text { Multiple } \\
\text { constituency or } \\
\text { social } \\
\text { constructivism }\end{array}$ & $\begin{array}{l}\text { Stakeholders' assessment of effectiveness (Smith \& } \\
\text { Shen, 1996; Herman et al., 1991; Taylor et al., 1991; } \\
\text { Herman, 1990; Schmid, 2002) }\end{array}$ \\
\hline
\end{tabular}

Researchers some times combined two or three approaches to assess nonprofit effectiveness. For example, Green and Griesinger (1996) combined the goal-attainment and system resource approaches to assess organizational effectiveness.

\subsection{Relationship between governance and effectiveness}

Most of the studies on effectiveness focus on the relationship between governance and effectiveness (Forbes, 1998). Normatively, governance is considered as the BOD's responsibility (Bradshaw et al., 1998; Saidel, 1998; Carver, 1996, 2001). A large portion of the governance-effectiveness literature stream focuses on associations between the characteristics of the BOD and organizational effectiveness and governance structure.

Three aspects of governance are examined in the literature: governance structure, BOD's practice, and BOD composition. Table 2 identifies the dimensions for governance drawn 
from the literature review.

Table 2: Aspects and dimensions for governance drawn from the literature review

\begin{tabular}{|c|c|}
\hline Aspect & Dimension \\
\hline \multirow[t]{4}{*}{$\begin{array}{l}\text { Governance } \\
\text { structure }\end{array}$} & $\begin{array}{l}\text { Centralization of authority (Carter et al., 1994; Glisson \& Martin, } \\
\text { 1980; Kushner \& Poole, 1996; Schmid, 2002) }\end{array}$ \\
\hline & $\begin{array}{l}\text { Hierarchy of authority (Glisson \& Martin, 1980; Kushner \& Poole, } \\
\text { 1996; Schmid, 2002) }\end{array}$ \\
\hline & $\begin{array}{l}\text { Structure formalization (Bradshaw et al., 1992; Glisson \& Martin, } \\
\text { 1980; Kushner \& Poole, 1996; Smith \& Shen, 1996) }\end{array}$ \\
\hline & Power distribution pattern in and around BOD (Murray et al., 1992) \\
\hline $\begin{array}{l}\text { BOD's } \\
\text { practices }\end{array}$ & $\begin{array}{l}\text { Activity breakdown (Bradshaw et al., 1992; Green \& Griesinger, } \\
\text { 1996; Kushner \& Poole, 1996) }\end{array}$ \\
\hline \multirow[t]{4}{*}{$\begin{array}{l}\text { BOD's } \\
\text { composition }\end{array}$} & $\begin{array}{l}\text { Occupation and skills of BOD members (Siciliano, 1990; Chait et } \\
\text { al., 1996) }\end{array}$ \\
\hline & Position in company (Siciliano, 1990) \\
\hline & Prestige of BOD member (Provan, 1980) \\
\hline & External linkages (Provan, 1980) \\
\hline
\end{tabular}

\subsubsection{NPO governance structures}

Scholars have researched NPO governance structures (Hult \& Walcott, 1990; Kushner \& Poole, 1996). Governance structure refers to "who participates in decision making" (Hult \& Walcott, 1990).

The extent of centrality and hierarchy of governance structures are highlighted (Glisson \& Martin, 1980; Kushner \& Poole, 1996; Schmid, 2002). Carter et al. (1994) found that centralization of authority will improve effectiveness in terms of productivity and market 
share. For human service NPOs, a highly centralized structure of authority is the most powerful, direct determinant of effectiveness in terms of productivity and efficiency (Glisson \& Martin, 1980; Kushner \& Poole; 1996).

Structure formalization is concerned about the existence of formalized rules, procedures, and guideline. Kushner and Poole (1996) and other scholars (Bradshaw et al., 1992; Glisson and Martin, 1980; Smith \& Shen, 1996) reported that a high level of structure formalization generates large clientele and high revenues. Smith and Shen (1996) also found that formalization can improve reputational effectiveness.

The governance structure-effectiveness relationship is also studied from the perspective of the pattern of power distribution in and around the BOD (Murray et al., 1992). Murray et al. reported that BODs with fragmented power and powerless BODs are associated with subjective perceptions of poor performance of the nonprofit.

\subsubsection{BOD's practice}

Prescriptive responsibilities that BODs are expected to meet are based both in legal requirements and moral assumptions (Herman \& Heimovics, 1991). BOD responsibilities have been linked to NPO effectiveness (Bradshaw et al., 1992; Kushner \& Poole, 1996).

The practitioner literature has contributed best practices for the BOD. Houle (1989) listed eleven functions of the governing BOD. National Center for Nonprofit Boards' (NCNB) adopted this list of governance functions and slightly modified it into. The list of 
governance functions includes: (i) determine the organization's mission and purpose, (ii) select and support the executive, and review her or his performance, (iii) approve and monitor the organization's programs and services, (iv) raise money, (v) ensure effective fiscal management, (vi) engage in strategic planning, (vii) enhance the organization's public image, (viii) develop itself as a BOD, from recruitment through assessing its own performance, (ix) understand the relationship between staff, BOD, and other volunteers, (x) organize itself so that the BOD operates effectively, and (xi) ensure sound risk management policies.

Carver's (1996, 2001) "policy governance" model defines "who should do what" in an NPO. The main idea of this model is that the BOD should always do "governance and policy-making" while the staff should perform "administration and management". He defines "policy" including both value and perspectives, which are "powerful, often invisible forces". He deems policy clarification as the central function of BOD leadership. Carver (1996, 2001) identifies four categories for BOD policy: (i) Ends, (ii) Executive Limitations, (iii) BOD-Executive Relationship, and (iv) BOD Process.

Crittenden et al. (1988) found that the presence of certain types of strategic planning activities was significantly associated with organizational effectiveness measured by stakeholder satisfaction. Activities, such as the analysis of strategic alternatives and the planning of implementation details contribute most to effectiveness. Siciliano (1997) reported similar results. 
Bradshaw et al. (1992) found that BOD processes, especially the use of strategic planning techniques and the existence of a common vision on the BOD, contributes to organizational effectiveness measured by both financial and reputational factors.

Green and Griesinger (1996) used the goal-attainment approach to study the relationship between BOD performance and organizational effectiveness in human service organizations. Thirty-three activities in nine areas of BOD responsibility were examined. They found that BOD activities in policy formation, strategic planning, program review, BOD development, resource development, financial planning, control, and dispute resolution affected organizational effectiveness.

Kushner and Poole (1996) found that organizations which do not conform to the NCNB standards have low performance, while those that conform to NCNB standards have high performance.

"Self-Assessment for Nonprofit Boards" (Slesinger, 1991) and "Governance Self-assessment Checklist" (GSAC) (Gill et al., 2005) were developed to assist BOD of NPO and public sector organizations on BOD's practice. Slesinger (1991) and Gill et al. (2005) reported the scores that the BODs achieve using these self-evaluation tools are positively related to overall organization effectiveness. Table 3 shows the GSAC subscales. 
Table 3: GSAC subscales

\begin{tabular}{|c|c|c|}
\hline $\begin{array}{l}\text { BOD } \\
\text { Effectiveness } \\
\text { quick check }\end{array}$ & & $\begin{array}{l}\text { Fifteen items identified in the literature as successful } \\
\text { governance }\end{array}$ \\
\hline BOD Structure & & $\begin{array}{l}\text { Assess the extent to which the BOD has the clarity of } \\
\text { structure necessary for effective governance, including } \\
\text { bylaw, policies, and role descriptions }\end{array}$ \\
\hline BOD Culture & & $\begin{array}{l}\text { Examine BOD dynamics, organizational values, } \\
\text { communication styles, and degree of trust }\end{array}$ \\
\hline \multirow[t]{6}{*}{$\begin{array}{l}\text { BOD } \\
\text { Responsibilities }\end{array}$} & $\begin{array}{l}\text { Mission and } \\
\text { planning }\end{array}$ & $\begin{array}{l}\text { Measures the level of BOD engagement in planning, } \\
\text { agreement on direction, and clarity of objectives }\end{array}$ \\
\hline & $\begin{array}{l}\text { Financial } \\
\text { stewardship }\end{array}$ & $\begin{array}{l}\text { Assess the degree to which the BOD scrutinizes finances } \\
\text { and the existence of sound financial practices as well as } \\
\text { the extent to which the BOD maintains a degree of } \\
\text { objectivity and independence from management }\end{array}$ \\
\hline & $\begin{array}{l}\text { Human Resources } \\
\text { Stewardship }\end{array}$ & $\begin{array}{l}\text { Taps the level of BOD support for the executive director, } \\
\text { its evaluation of his or her performance, and its oversight } \\
\text { of other human resource practices such as BOD and senior } \\
\text { management succession planning }\end{array}$ \\
\hline & $\begin{array}{l}\text { Performance } \\
\text { Monitoring and } \\
\text { Accountability }\end{array}$ & $\begin{array}{l}\text { Evaluate the care with which the BOD monitors } \\
\text { information and results, the adequacy of the BOD's } \\
\text { accountability to stakeholders, and the extent to which it } \\
\text { ensures fair dispute-resolution processes }\end{array}$ \\
\hline & $\begin{array}{l}\text { Community } \\
\text { Representation and } \\
\text { Advocacy }\end{array}$ & $\begin{array}{l}\text { Assess communication practices, stakeholder input, and } \\
\text { whether nomination processes generate BOD membership } \\
\text { that adequately represents community diversity }\end{array}$ \\
\hline & Risk Management & $\begin{array}{l}\text { Evaluate the regularity of review of bylaws and policies, } \\
\text { compliance with these and with relevant legislation, and } \\
\text { safeguarding against financial and other risks }\end{array}$ \\
\hline \multirow[t]{2}{*}{$\begin{array}{l}\text { BOD Processes } \\
\text { and Practices }\end{array}$} & BOD Development & $\begin{array}{l}\text { Assess practices related to recruitment and orientation of } \\
\text { BOD members, team building, and BOD self-assessment }\end{array}$ \\
\hline & BOD Management & $\begin{array}{l}\text { Evaluate conflict management, respect for roles, and } \\
\text { distribution of work and power }\end{array}$ \\
\hline
\end{tabular}




\subsubsection{BOD composition}

Provan (1980) found that BOD member's prestige and linkages contribute to organizational effectiveness measured by absolute funding levels.

The relationship between BOD members' diversity and organizational effectiveness has been examined (Siciliano, 1990; Chait et al., 1996). Occupation diversity was found to significantly contribute to effectiveness.

Although governance covers aspects other than governance structure, BOD practice, and BOD members' composition, these three aspects are the major constructs of governance. Researchers have tested the relationship between these three constructs and organizational effectiveness. The selection of constructs, dimensions, and metrics is to large extent based on the researchers' judgments and perspectives. This is a weakness of the literature in the governance-effectiveness stream (Forbes, 1998).

\subsection{Open source software foundation}

\subsubsection{Why open source software communities need foundations}

Communities are not legal actors. The lack of legal rights of online communities creates dilemmas: they can not protect the concepts and trademarks or cooperate and contract with commercial firms (O’Mahony, 2003b).

\subsubsection{OSSF governance and effectiveness}

Fortune 500 firms were challenged for the idea of "collaborating with a web page". As a 
result, Apache, Debian, Gnu, GNOME, FreeBSD, Jabber, Perl, Python, KDE, BND, the Linux Standards Base and Chandler designed private non-profit foundations to "host" their projects (O’Mahony, 2003b).

Various researchers have examined OSS community governance (Lattemann \& Stieglitz, 2005; Markus et al., 2000; West \& O’Mahony, 2005; O’Mahony \& Ferraro, 2007). However, no researcher has examined the governance of OSSF. However the context and the forces which drive organizations to adopt governance structures are different at the community and foundation levels. The literature in this stream offers little insights on governance at the foundation level.

Occasionally, the open source software literature addresses some aspects of OSSF governance. For example, Dueñas et al. (2007) discussed the incubation process, which is one aspect of project governance in open source foundations.

The open source software literature has not examined governance in OSSF.

Most of the OSSFs are membership based organizations (O'Mahony, 2003b). However, the literature on nonprofits focuses on NPOs such as human service organizations, art museums, hospitals, and so on, which are not membership based. Few researchers (Spear, 2004; Schnurbein, 2006) examine membership oriented organizations. The literature in both of these streams agrees that the BOD is the core actor in governance. 
DeLone and McLean $(1992,2002,2003)$, Crowston et al. $(2004,2006)$ assess open source software project effectiveness and performance. Open source project effectiveness is one aspect of OSSF effectiveness. Other aspects of OSSF effectiveness have not been examined.

\subsection{Company involvement in OSSF}

Firms have various motives for becoming involved in open source projects and communities. These include: identifying opportunities for future collaboration (Rosenkopf et al, 2001), sharing the risk of developing innovations which might affect industry standards (Gabriel \& Goldman, 2005; Koenig 2004; West \& O'Mahony, 2005), increasing the demand for complementary products (Bonaccorsi \& Rossi, 2004; Hawkins, 2004; Lerner \& Tirole, 2004), using OSS as low cost components (Bonaccorsi \& Rossi, 2004; Hawkins 2004), implementing strategies (Henkel, 2003, Koenig, 004), benefiting from external support (Bonaccorsi \& Rossi, 2004; Gabriel \& Goldman, 2005), gaining reputation (Henkel, 2003), and generating revenues on complementary services (Bonaccorsi \& Rossi, 2004; Wichmann, 2002; West \& O'Mahony, 2005).

New business models that allow companies to generate revenue from open source have been developed (Nissila, 2004). Researchers identified several open source business models (Hecker, 1999; Spiller \& Wichmann, 2002). Generally, open source business models emphasise generating value by utilizing resources that lie outside of the firm's boundary (Hope 2003). 
Firms which have business models related to OSS can become involved in the development of open source software by sponsoring and hiring developers (O’Mahony, 2003b). Also firms can directly initiate open source project-pooled research and development (R\&D) and spinout projects (West \& Gallagher, 2006). Pooled R\&D begins as a community and spinout project. It begins with internal development and later external contributors join. Some firm initiated projects are a mix of both formats. Examples for pooled R\&D would be Eclipse, while Mozilla and Jikes are examples of spinout projects (O'Mahony \& West, 2004).

O'Mahony (2003) suggests that companies invest resources and manpower in open source foundations, and in return obtain advisory and sponsor roles that allow them to have a "voice in the foundation". This can be defined as influence. For a BOD member, influence is the relational treatment of power. According to the research by Pettigrew and Mcnulty (1995), a BOD member's power and influence is contingent on three sets of factors: context and structure, power sources, and will and skill. They used semi-structured interviews incorporated with BOD member background and career information to examine power and influence on corporation BODs.

Table 4 provides the constructs and dimensions for company involvement drawn from the literature review. 
Table 4: Constructs and dimensions for company involvement drawn from the literature review

\begin{tabular}{|l|l|}
\hline Construct & Dimension \\
\hline Company investment & Resource investment \\
\cline { 2 - 2 } & Manpower investment \\
\hline Company influence & Context and structure \\
\cline { 2 - 2 } & Source of power \\
\cline { 2 - 2 } & Will and skill \\
\hline
\end{tabular}

\subsection{Lessons learned}

(i) Research on OSSF governance and effectiveness is scant. Not much has been published on this topic in the OSS and nonprofit literature streams

(ii) The assessment of nonprofit effectiveness requires multiple dimensions

(iii) BOD is the major actor in the governance of membership based nonprofits

(iv) There are two types of OSS NPOs under the US tax exempt code: 501(c)(3) and 501(c)(6). 501(c)(3) NPOs are for pubic interests, while 501(c)(6) NPOs are for member business interests

(v) Constructs, dimensions, and metrics for company involvement, governance, and effectiveness identified from the literature review

Table 5 identifies the constructs, dimensions and metrics for company involvement, governance and effectiveness drawn from the literature review. It synthesizes information provided in Tables 1, 2, and 4 in Chapter 2. 
Table 5: Constructs, dimensions and metrics drawn from the literature review

\begin{tabular}{|c|c|c|}
\hline Domain & Construct & Dimension \\
\hline \multirow{4}{*}{$\begin{array}{l}\text { Company } \\
\text { involvement }\end{array}$} & \multirow[t]{2}{*}{ Company investment } & Resource investment \\
\hline & & Manpower investment \\
\hline & \multirow[t]{2}{*}{ Company influence } & Source of power over OSSF \\
\hline & & Will and skill \\
\hline \multirow[t]{9}{*}{ Governance } & \multirow[t]{4}{*}{ Governance structure } & Centralization of authority \\
\hline & & Hierarchy of authority \\
\hline & & Structure formalization \\
\hline & & Power distribution pattern \\
\hline & BOD's practices & Activity breakdown \\
\hline & \multirow[t]{4}{*}{ BOD composition } & Occupation and skills of BOD members \\
\hline & & Position in company \\
\hline & & Prestige of BOD member \\
\hline & & External linkages \\
\hline \multirow[t]{4}{*}{ Effectiveness } & Goal attainment & Productivity \\
\hline & \multirow[t]{2}{*}{ System resources } & Financial resources \\
\hline & & Other resources \\
\hline & $\begin{array}{l}\text { Multiple constituency } \\
\text { or social } \\
\text { constructivism }\end{array}$ & Stakeholders' assessment of effectiveness \\
\hline
\end{tabular}

(vi) The link between governance and foundation effectiveness is well established in the literature (e.g. Glisson \& Martin, 1980; Provan, 1980; Siciliano, 1990; Bradshaw et al., 1992; Carter et al., 1994; Kushner \& Poole, 1996; Forbes, 1998; Schmid, 2002). The literature suggested that there is link between company involvement and governance (O'Mahony, 2003b). It is unknown whether or not a link exists between company involvement and foundation effectiveness 
Figure 1 illustrates the relationship among company involvement, governance, and OSSF effectiveness suggested by the literature review.

Figure 1: Relationship among company involvement, governance and effectiveness drawn from the literature review

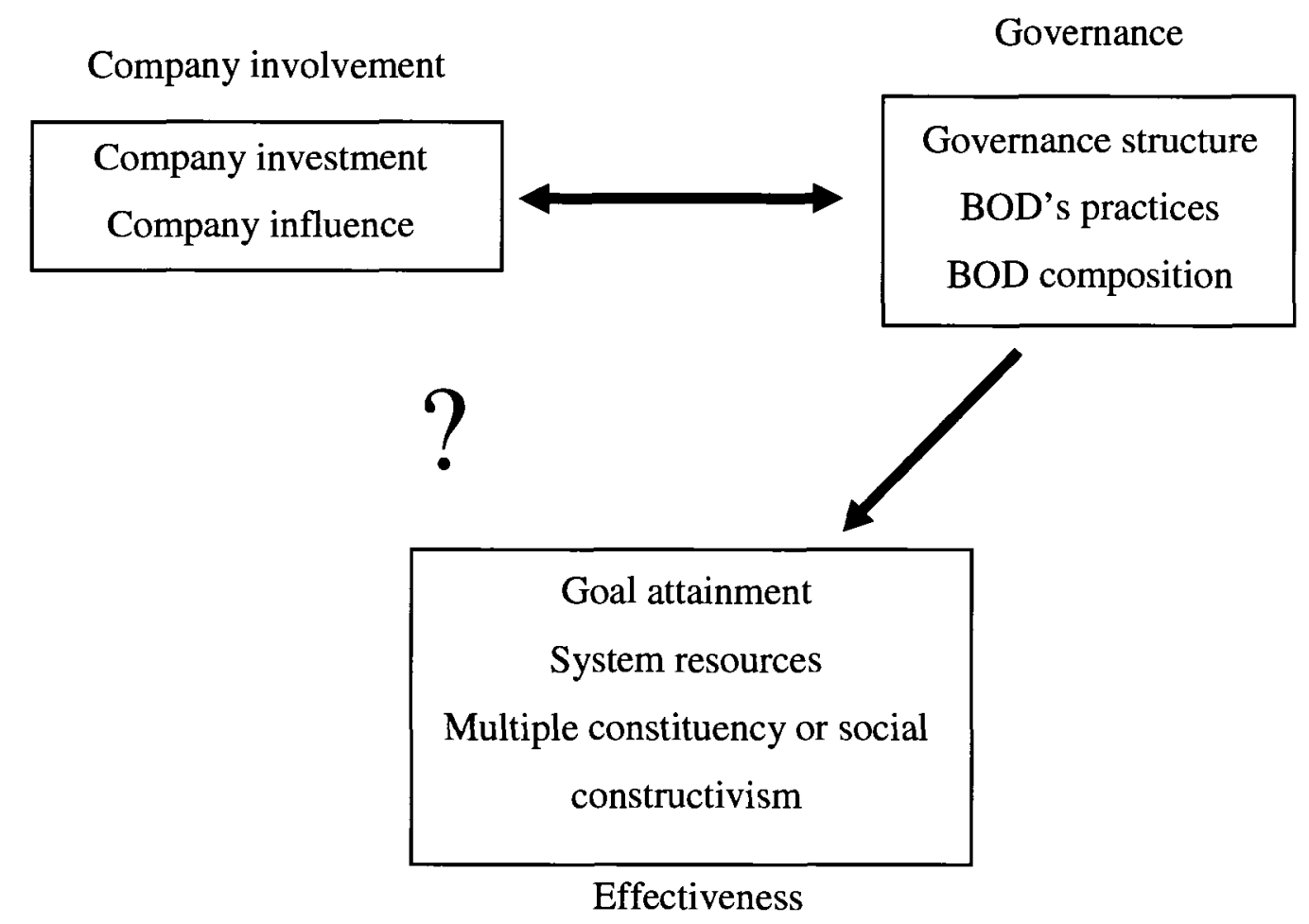




\section{RESEARCH METHOD}

This chapter is organized into three sections. Section 3.1 describes the unit of analysis.

Section 3.2 describes the study period. Section 3.3 describes the research method.

\subsection{Unit of analysis}

The unit of analysis is the open source foundation operating at least one active open source software project.

\subsection{Study period}

The study period is from January 1, 2003 to December 31, 2006.

The start and end date of the financial years of the foundations in the sample fall within January 1, 2003 and December 31, 2006.

\subsection{Research method}

Table 5 provides the ten steps of the method used in this research. 
Table 5: Research method

\begin{tabular}{|c|c|c|}
\hline $\begin{array}{l}\text { Step } \\
\text { No. }\end{array}$ & Dominant activity carried out & Outcome \\
\hline 1 & Set criteria for sample selection & Criteria to select sample \\
\hline 2 & $\begin{array}{l}\text { Assemble list of open source software } \\
\text { foundations and select sample }\end{array}$ & Sample \\
\hline 3 & $\begin{array}{l}\text { Identify constructs and dimensions for } \\
\text { company involvement, governance and OSSF } \\
\text { effectiveness from literature review }\end{array}$ & $\begin{array}{l}\text { Version } 1 \text { of the constructs and } \\
\text { dimensions for company } \\
\text { involvement, governance and OSS } \\
\text { effectiveness }\end{array}$ \\
\hline 4 & Identify and collect information on constructs & $\begin{array}{l}\text { Version } 2 \text { of the constructs, } \\
\text { dimensions, and metrics of } \\
\text { company involvement, governance } \\
\text { and OSSF effectiveness }\end{array}$ \\
\hline 5 & Collected data for metrics of the constructs & Electronic database \\
\hline 6 & $\begin{array}{l}\text { Identify categories for company involvement, } \\
\text { governance and OSSF effectiveness and links } \\
\text { between them }\end{array}$ & $\begin{array}{l}\text { Categories and links across } \\
\text { categories }\end{array}$ \\
\hline 7 & $\begin{array}{l}\text { Identify BOD activities, how they breakdown, } \\
\text { and links to categories previous identified }\end{array}$ & $\begin{array}{l}\text { Breakdown of BOD activities and } \\
\text { links to other categories }\end{array}$ \\
\hline 8 & $\begin{array}{l}\text { Develop model and propositions anchored } \\
\text { around the model }\end{array}$ & Model and propositions \\
\hline 9 & Answer research questions & Answers to research questions \\
\hline 10 & $\begin{array}{l}\text { Link results to the literature and generate } \\
\text { observations }\end{array}$ & $\begin{array}{l}\text { Set of relevant links to the } \\
\text { literature and list of observations }\end{array}$ \\
\hline
\end{tabular}

\subsubsection{Set criteria for sample selection}

Foundations in the sample should

(i) Be registered in the United States, and have 501(C) tax exempt status in 2008 
(ii) Host at least one active open source software project

(iii) Have public available financial data and records of governance activities for at least two consecutive years

Most of the OSSFs are registered in the United States. Thus, it is reasonable to limit the sample to OSSFs incorporated in the United States.

501(C) tax exempt status is evidence that an organization is a nonprofit. It must have at the very least formal financial records. This criterion excludes open source organizations which are not mature enough to be legal entities. This ensures that OSSFs in the sample have similar internal and external contexts.

Historical data is needed to compare OSSF. Thus, it was required that each foundation in the sample should have at least two years of publicly available information on its financial and governance activities. However, some important OSSFs (e.g., OpenBSD, FreeBSD, Perl, and etc.) were excluded because there was no public governance information available.

\subsubsection{Assemble list of open source software foundations and select sample}

To select the sample, a list of open source organizations was created first. Sources for these organizations were: Wikipedia's list of free and open source software 
organizations ${ }^{3}$, Google's summer code mentoring organization list ${ }^{4}$, and the first ten pages of Google search results for the following keywords: "open source foundations OR nonprofit OR organization". The search was carried out on November 1, 2007.

Second, the researcher first searched the official website of each open source organization in the list and identified its status of incorporation. The researcher then removed the organizations that were not incorporated.

Third, the researcher first searched for the official incorporation and tax exempt documents of each organization left on the list. The researcher then removed organizations if they were incorporated outside of the United States or did not have 501(C) tax exempt status in 2008.

Fourth, the researcher first searched for the software projects of the organizations left on the list. The researcher then removed the organizations that did not host at least one open source software project that introduced a new software release in 2007.

Fifth, the researcher first searched for the financial reports, annual reports, and meeting records of the organizations left on the list. The researcher then removed the organizations which did not have at least two years of information on financial and governance activities.

\footnotetext{
${ }^{3}$ http://en.wikipedia.org/wiki/Category:Free and open source software organizations

${ }^{4}$ http://code.google.com/soc/2007/
} 


\subsubsection{Identify constructs and dimensions from the literature review}

\section{Company involvement}

The extant literature conceptualizes company involvement comprised of company investment and company influence. Companies are thought of influencing OSSFs by investing resources and hiring or sponsoring people in OSSFs (O'Mahony, 2003b). O'Mahony (2003) suggests that company investment refers to resource investment and manpower investment.

In return for their investment, companies may receive roles as advisors, sponsors, or BOD members of the OSSF (O'Mahony, 2003b). This enables companies to directly influence OSSF governance.

The researcher decided not to consider indirect company influence. Company employees hold a significant proportion of seats on the BOD of the OSSFs. Thus, the indirect influence would be rather small compared to direct influence. For the purpose of this research, company influence means direct influence or "who participates in decision-making" (Hult \& Walcott, 1990).

\section{Governance}

Because company involvement, governance, and effectiveness relation is the major concern in this research, aspects of governance which are not included in the governance-effectiveness literature stream are excluded from this research. 
Table 2 in Chapter 2 identified three governance constructs drawn from the governance-effectiveness literature stream: governance structure, BOD's practices, and BOD's composition.

Governance structure is about who can make what decision (Hult \& Walcott, 1990). For the purpose of this research, governance structure is comprised of governance instruments, the criteria on who can be part of the governance instruments, and the scope of rights for the members in governance instruments.

BOD's practices consider the existence of certain governance processes, formality of governance processes, and governance activities undertaken by the BOD.

BOD composition focuses on the background information of BOD members, such as occupation, position in company, prestige, and linkages. Background information indicates skill, power and will of BOD (Provan, 1980; Siciliano, 1996).

\section{Effectiveness}

Different dimensions can be used to evaluate effectiveness (Forbes, 1998). The researcher identified dimensions and measurable metrics for effectiveness found in records maintained by the OSSFs in the sample. 


\subsubsection{Identify and collect data on constructs}

The researcher examined the records maintained by the OSSFs in the sample to better understand what dimensions and metrics were most suitable for each of the constructs being examined.

Most OSSFs are membership based nonprofits. Thus, the characteristics of membership based nonprofits need to be reflected in this step.

Company influence on the BOD of OSSF was examined in this research. Schnurbein (2006) argued that the BOD is the dominant group in the governance structure of a membership based nonprofit. To identify dimensions and metrics for company influence, background information on the BOD was collected (Pettigrew \& Mcnulty, 1995; Siciliano, 1996). Special attention was paid to information on the employment of members of BOD.

Constructs for governance drawn from the governance-effectiveness literature stream were used in this research. Governance structure was examined following BOD-member relationship proposed by Schnurbein (2006). To identify dimensions and metrics for governance structure, information was collected on the bylaws and governance policies maintained by OSSFs in their official websites. This information included the descriptions of governance instruments, criteria for becoming a member in governance instruments, and scope of member rights, which reflects the extent to which the members of the OSSFs can shape the BOD's composition and decisions. 
To identify dimensions and metrics for effectiveness, the researcher examined annual reports and BOD and member meeting records. Metrics which are used by members of the BOD or other officers to reflect performance were collected.

\subsubsection{Collect data for identified metrics}

Data for metrics drawn from the literature and public information was collected.

For each OSSF in the sample,

(i) From the OSSFs' official websites, companies' websites, BOD and member meeting minutes, press release, personal web blog, third party interview, and third party reputation ranking, the following information was collected for each member of the BOD of the OSSF: profession, company association, position in companies, and reputation.

(ii) From the bylaw, charter and other official governance documents on OSSF official websites, information on formal governance process and governance instruments was collected

(iii) From OSSF websites, web blog, interview, presentations on OSS conference, annual reports, financial report, press releases, third party interview, and free statistics from information vendors, information on effectiveness metrics was collected 


\section{Sources of information}

The sources of information included: OSSF websites, company websites, web blog, Wikipedia, interview, presentations on OSS conference, annual reports, financial report, bylaw, charter, official governance documents, press releases, third party interview, third party statistics, and free statistics from information vendors. Various data search tools are used, including Guidestar ${ }^{5}$ and Google ${ }^{6}$.

Table 6 provides the sources of information for company involvement, governance, and effectiveness.

${ }^{s}$ http://www.guidestar.org. Nonprofits financial statement web search tool

${ }^{6}$ http://www.google.com. General purpose web search tool 
Table 6: Sources of information

\begin{tabular}{|l|l|}
\hline & Sources of information \\
\hline Company & $\begin{array}{l}\text { OSSF official website } \\
\text { Company web site } \\
\text { Annual report } \\
\text { BOD meeting minutes } \\
\text { Member meeting minutes } \\
\text { Presentation on OSS conference } \\
\text { Personal web blog }\end{array}$ \\
\hline Governance & $\begin{array}{l}\text { Bylaw } \\
\text { Charter } \\
\text { Other official governance documents } \\
\text { Third party reputation ranking on members }\end{array}$ \\
\hline Effectiveness & $\begin{array}{l}\text { BOD meeting minutes } \\
\text { Member meeting minutes } \\
\text { Financial report } \\
\text { Annual report } \\
\text { Presentation for OS conference } \\
\text { Web blog } \\
\text { Wikipedia } \\
\text { Interview } \\
\text { Free statistics from information vendors }\end{array}$ \\
\hline
\end{tabular}

\subsubsection{Identify categories and linkages}

OSSFs were first categorized based on the metrics for which data could be obtained and then links between categories were identified.

\subsubsection{Identify BOD activity breakdown, and links}

For each OSSF in the sample, the researcher collected information on BOD governance practices by examining BOD meeting records. These records identify the activities 
undertaken by the members of BOD or those that were undertaken by external organizations or staffs at the request of the BOD.

Published catalogs of governance activities for nonprofits (Houle, 1989; Slesinger, 1991; Gill et al., 2005) were referenced in the process of categorizing.

A count for each governance activity was identified. The unit counted is activity per month. Thus, if an activity is performed over two months, the count is two. OSSFs were compared based on whether activities were undertaken by (i) members of the BOD or (ii) staff in organizations outside of the BOD. For each OSSF in the sample, a breakdown of the BOD activities was obtained by calculating the ratio of the count of each catalog activity to the total count of activities.

OSSFs in the sample were also categorized based on the nature of their policies and guidelines. Links between categories of BOD's activity breakdown and the content of policies and guidelines were identified.

\subsubsection{Develop model and propositions anchored around the model}

A research model that explains the relationship among company investment, governance, and foundation effectiveness was developed. Propositions anchored around the model were developed. 


\subsubsection{Answer research questions}

Results of the research were used to answer the four research questions.

\subsubsection{Link results to the literature and generate observations}

The results of this research were compared with the results of the studies reviewed in

Chapter 2. 


\section{RESULTS}

This chapter is organized into five sections. Section 4.1 describes the sample used in this research. Section 4.2 provides the dimension and metrics for company involvement, governance, and OSSF effectiveness drawn from publicly available information. Section 4.3 shows OSSFs categorized using the dimensions for which data exists. Section 4.4 provides the model generated, and the propositions anchored around it.

\subsection{Sample}

Appendix 1 provides a list of the thirty incorporated open source software foundations which were identified following the method described in section 3.3.2 on November 2007. For each foundation, Appendix 1 shows: (i) whether or not it holds 501(C) tax exempt status in the United States; (ii) whether or not it is responsible for at least one active open source project; and (iii) whether or not financial data and records of governance activities are publicly available for at least two consecutive years.

Six open source foundations listed in Appendix 1 met the sample selection criteria. Table 7 identifies the six OSSFs included in the sample used for this research. Five of the foundations hold 501(c) tax exempt status and one holds 501(c)(6) tax exempt status. SPI is the oldest foundation (almost 10 years old), while Plone is the youngest (three years old). 
Table 7: OSSFs included in the sample

\begin{tabular}{|c|c|c|c|c|c|}
\hline No & Foundation name & $\begin{array}{l}\text { Legal } \\
\text { type }\end{array}$ & Official website & $\begin{array}{l}\text { Type of code of } \\
\text { major project }\end{array}$ & $\begin{array}{l}\text { Year } \\
\text { founded }\end{array}$ \\
\hline 1 & $\begin{array}{l}\text { Apache Software } \\
\text { Foundation }\end{array}$ & $501(\mathrm{c})(3)$ & http://www.apache.org/ & $\begin{array}{l}\text { Networking/Internet } \\
\text { server }\end{array}$ & 2001 \\
\hline 2 & Eclipse Foundation & $501(\mathrm{c})(6)$ & http://www.eclipse.org/org/foundation/ & Development tool & 2003 \\
\hline 3 & $\begin{array}{l}\text { GNOME } \\
\text { Foundation }\end{array}$ & $501(\mathrm{c})(3)$ & http://foundation.gnome.org/ & Desktop platform & 2002 \\
\hline 4 & Plone Foundation $^{7}$ & $501(\mathrm{c})(3)$ & http://plone.org/foundation & $\begin{array}{l}\text { Content } \\
\text { management }\end{array}$ & 2004 \\
\hline 5 & $\begin{array}{l}\text { Python Software } \\
\text { Foundation }\end{array}$ & $501(\mathrm{c})(3)$ & http://python.org/psf/ & $\begin{array}{l}\text { Programming } \\
\text { language }\end{array}$ & 2001 \\
\hline 6 & $\begin{array}{l}\text { Software in the } \\
\text { Public Interest }\end{array}$ & $501(\mathrm{c})(3)$ & http://spi-inc.org/ & Operating system & 1997 \\
\hline
\end{tabular}

The Apache Software Foundation was incorporated in Delaware in 1999 by the members of the Apache group. Initially, the Apache Software Foundations was to support the Apache HTTP server project. In 2008, the Apache Software Foundation hosted 65 open source software projects, with 1765 committers $^{8}$.

The Apache Software Foundation has a meritocracy based membership structure, and has a large and mature open source community. Its organizational structures, processes, and policies served as examples for other OSSFs, such as the Plone Foundation ${ }^{9}$. The Apache Software Foundation has earned a reputation for incubating open source software project

7 Plone foundation is founded in late 2004. So data for Plone foundation only covered 2005 and 2006.

${ }^{8}$ http://involve.jisc.ac.uk/wpmu/oss-watch/2008/06/03/just-how-big-is-the-apache-software-foundation/

9 http://plone.org/foundation 
(Dueñas et al., 2007).

IBM released as open source the code of the Eclipse project and formed the Eclipse consortium in 2001. In 2004, the Eclipse consortium was reorganized into the Eclipse Foundation, a 501(c)(6) nonprofit. Unlike most other open source organizations, the Eclipse Foundation is for its members' business interests. In 2008, the Eclipse Foundation hosted 11 top level projects with 21 strategic members, 179 organizational members, and 942 committers in $2008^{10}$. Eclipse is dominant in the market for Java Integrated Development Environments (IDE) ${ }^{11}$.

The Eclipse Foundation has a large and established community sponsored and controlled by companies (Helander et al., 2007; O'Mahony \& West, 2004; West \& Gallagher, 2006; Capek et al., 200). It is a known example of commercial open source phenomenon (also known as OSS 2.0) (Fitzgerald, 2006). The incubator process used by the Eclipse Foundation is very efficient (Dueñas et al., 2007).

GNOME is part of the GNU project and it was a subproject hosted by SPI ${ }^{12}$. The GNOME Foundation was founded in 1997 by Miguel de Icaza and Federico Mena. The GNOME Foundation hosts the GNOME project which provides a desktop environment and development platform. It also hosts numerous other projects relevant to the GNOME

\footnotetext{
${ }^{10} \mathrm{http}: / /$ www.eclipse.org/org/foundation/membersminutes/20080317MembersMeeting/2008-03-17-Jumpstart.pdf

11 http://ieeexplore.ieee.org/iel5/2/31455/01463097.pdf?arnumber=1463097

12 http://www.spi-inc.org/projects
} 
project. The GNOME desktop environment is one of the dominant desktop environments in the Linux desktop.

The GNOME Foundation has a large and established community (Helander et al., 2007).

The Plone Foundation was founded by Alexander Limi, Alan Runyan, and Vidar Andersen in 2004 to support the development of Plone, which is a free and open source content management system. Plone have a rather small market share in content management system, but it is deemed as one of the best in the market ${ }^{13}$.

The Plone Foundation has a meritocracy based membership structure. Many small open source consultant and service vendors are part of the Plone community (Michlmayr, 2007).

The Python Software Foundation was founded by Guido Van Rossum in 2001 as an organization devoted to the Python programming language, one of the leading script programming languages.

The Software in the Public Interest (SPI) was formed by members of Debian project in 1997. Its mission is to "help organizations develop and distribute open hardware and software" ${ }^{\prime 14}$. It hosts several open source projects, such as Debian, freedesktop.org, and

\footnotetext{
${ }^{13}$ E.g. http://www.openadvantage.org/articles/oadocument.2005-04-19.0329097790

14 http://www.spi-inc.org/
} 
openOffice.org. GNOME was a subproject hosted by SPI before the GNOME Foundation was founded. SPI seldom intervenes in the affairs of its member projects, but it does hold their common assets (O’Mahony, 2003b).

\subsection{Dimensions and metrics identified from examining the data}

Appendix 2 shows the dimensions and metrics identified by examining information about the six OSSFs included in the sample.

Table 8 shows the metrics for which data for the study period was available. Table 8 only includes the metrics in Appendix 2 for which data exists. Metrics without data for the study period were not included in this research. 
Table 8: Metrics for which data exists

\begin{tabular}{|c|c|c|c|}
\hline Domain & Construct & Dimension & Metric \\
\hline $\begin{array}{l}\text { Company } \\
\text { involvement }\end{array}$ & $\begin{array}{l}\text { Company } \\
\text { investment } \\
\text { and } \\
\text { Company } \\
\text { influence }\end{array}$ & $\begin{array}{l}\text { Manpower } \\
\text { investment and } \\
\text { Employment }\end{array}$ & $\begin{array}{l}\text { 1-1. Number of members of BOD } \\
\text { 1-2. Number of company employees in BOD } \\
\text { 1-3. Number of employees in BOD from } \\
\text { companies that do not depend on OSSF's } \\
\text { projects for significant portion of revenue } \\
\text { 1-4. Number of BOD's members who work for } \\
\text { major sponsor companies } \\
\text { 1-5. Number of employees in BOD who are part } \\
\text { of companies' top management teams } \\
\text { 1-6. Number of employees in BOD who are part } \\
\text { of top management teams of companies } \\
\text { that do not depend on OSSF projects for } \\
\text { significant portion of revenue }\end{array}$ \\
\hline Governance & $\begin{array}{l}\text { Governance } \\
\text { structure }\end{array}$ & $\begin{array}{l}\text { Participation in } \\
\text { decision making }\end{array}$ & $\begin{array}{l}\text { 2-1. Member criteria } \\
\text { 2-2. Majority member by number } \\
\text { 2-3. Member constitution } \\
\text { 2-4. Whether or not merit members have voting } \\
\text { rights } \\
\text { 2-5. Whether or not merit members can submit } \\
\text { requirements } \\
\text { 2-6. Whether or not merit members have the } \\
\text { rights to approve policies and guidelines } \\
\text { 2-7. Whether or not merit members have the } \\
\text { rights to approve modifications to bylaw } \\
\text { 2-8. Whether or not merit members have the } \\
\text { rights to approve modifications to common } \\
\text { visions } \\
\text { 2-9. Whether or not merit members have the } \\
\text { rights to approve primary human resource } \\
\text { decisions } \\
\text { 2-10. Whether or not sponsor members have } \\
\text { voting rights }\end{array}$ \\
\hline
\end{tabular}




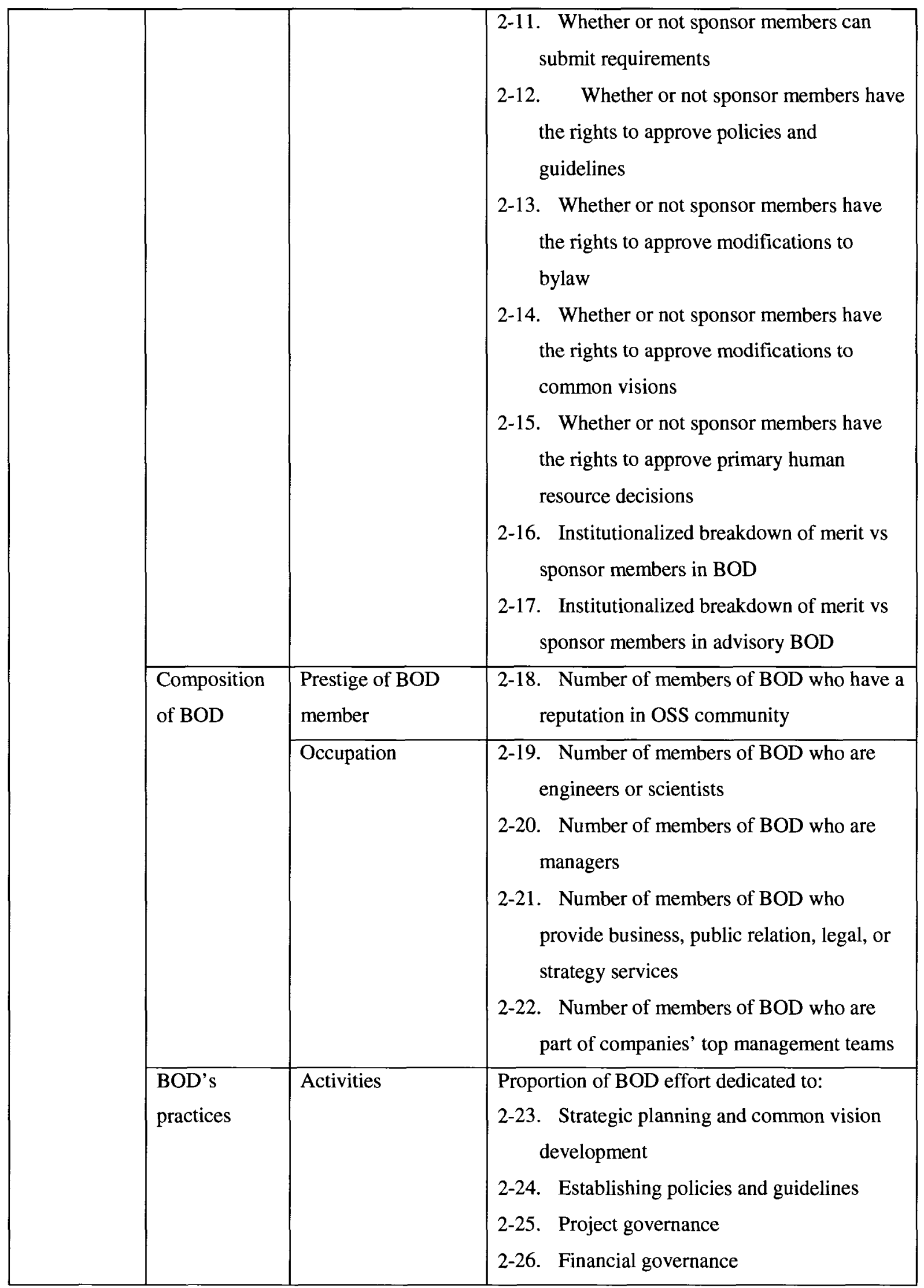




\begin{tabular}{|c|c|c|c|}
\hline & & & $\begin{array}{l}\text { 2-27. Primary resources governance } \\
\text { 2-28. Human resource governance } \\
\text { 2-29. Fund raising } \\
\text { 2-30. External relations } \\
\text { 2-31. BOD self development } \\
\text { 2-32. Governance structure management } \\
\text { 2-33. Community development } \\
\text { 2-34. Conference planning and delivery } \\
\text { Method to carry out governance activities } \\
\text { 2-35. Method to carry out governance } \\
\text { activities } \\
\text { Content of important policies } \\
\text { 2-36. Existence of umbrella policy } \\
\text { 2-37. Existence of incubation policy } \\
\text { 2-38. Extent to which committee of the BOD } \\
\text { has power over roadmap } \\
\text { 2-39. Extent to which committee of the BOD } \\
\text { has power over release schedule } \\
\text { 2-40. Restrictions on commercial usage }\end{array}$ \\
\hline \multirow[t]{3}{*}{ Effectiveness } & \multirow{2}{*}{$\begin{array}{l}\text { Goal } \\
\text { attainment }\end{array}$} & Project effectiveness & 3-1. Number of total projects operated by OSSF \\
\hline & & $\begin{array}{l}\text { Community } \\
\text { effectiveness }\end{array}$ & $\begin{array}{l}\text { 3-2. Number of members } \\
\text { 3-3. Number of merit members } \\
\text { 3-4. Number of sponsor members }\end{array}$ \\
\hline & $\begin{array}{l}\text { System } \\
\text { resources }\end{array}$ & $\begin{array}{l}\text { Resource acquisition } \\
\text { effectiveness }\end{array}$ & $\begin{array}{l}\text { 3-5. Revenue } \\
\text { 3-6. Major source of revenue }\end{array}$ \\
\hline
\end{tabular}




\subsection{Data and categories}

\subsubsection{Company involvement}

This section provides the result on the employment of BOD members. The intent is to show the degree to which companies can exert direct influence on the governance of the OSSFs in the sample. Employers of the BOD members were categorized based on their potential relationship to the OSSFs in the sample, such as relevant company, major sponsor, and companies that do not depend on OSSF's projects for significant portion of revenue. The BOD members' positions in their employers were also considered.

Table 9 shows the number and proportion of BOD positions held by company employees. The identification numbers (IDN) on the left column correspond to those shown in the right column in Table 8.

In Table 9, the metrics which were calculated using the data collected include: 1-2-1 Proportion of company employees in BOD, 1-3-1 Proportion of employees in BOD from companies that do not depend on OSSF's projects for significant portion of revenue, and 1-4-1 Proportion of employees in BOD from companies that are major sponsors of OSSF. Company employees in BOD stand for the members of the BOD who are employed by companies which generate revenues from OSSF's projects (relevant companies). Companies that do not depend on OSSF's projects for significant portion of revenue are those which have multiple revenue resources and do not solely rely on providing services or selling products based on the OSSF's projects. This type of companies will continue to operate even without the OSSF's projects. 
Table 9: Employees in BOD

\begin{tabular}{|c|l|c|c|c|c|c|c|}
\hline IDN & \multicolumn{1}{|c|}{ Metrics } & Apache & Python & SPI & Plone & Eclipse & GNOME \\
\hline $1-1$ & Number of members of BOD & 27 & 21 & 29 & 16 & 31 & 33 \\
\hline $1-2$ & $\begin{array}{l}\text { Number of company employees } \\
\text { in BOD }\end{array}$ & 17 & 13 & 15 & 16 & 31 & 22 \\
\hline $1-2-1$ & $\begin{array}{l}\text { Proportion of company } \\
\text { employees in BOD }\end{array}$ & $63 \%$ & $62 \%$ & $52 \%$ & $100 \%$ & $100 \%$ & $67 \%$ \\
\hline $1-3$ & $\begin{array}{l}\text { Number of employees in BOD } \\
\text { from companies that do not } \\
\text { depend on OSSF's projects for } \\
\text { significant portion of revenue }\end{array}$ & 10 & 11 & 7 & 5 & 27 & 18 \\
\hline $1-3-1$ & $\begin{array}{l}\text { Proportion of employees in } \\
\text { BOD from companies that do } \\
\text { not depend on OSSF's projects } \\
\text { for significant portion of } \\
\text { revenue }\end{array}$ & $37 \%$ & $52 \%$ & $24 \%$ & $31 \%$ & $87 \%$ & $55 \%$ \\
\hline $1-4$ & $\begin{array}{l}\text { Number of employees in BOD } \\
\text { from companies that are major } \\
\text { sponsors of OSSF }\end{array}$ & 10 & 6 & 4 & 8 & 26 & 20 \\
\hline $1-4-1$ & $\begin{array}{l}\text { Proportion of employees in } \\
\text { BOD from companies that are } \\
\text { major sponsors of OSSF }\end{array}$ & $37 \%$ & $29 \%$ & $14 \%$ & $50 \%$ & $84 \%$ & $61 \%$ \\
\hline
\end{tabular}

For Apache, Python, and GNOME, data on BOD members shown in Table 9 is for 2004, 2005, and 2006. For SPI, data on BOD members is for 2003, 2004, and 2005, for which is financial data is available. For Plone, data on BOD members is for 2005, and 2006, for which its financial data is available. For Eclipse, data on BOD members is for 2006. Data for 2004 and 2005 was not available. The bylaw, press releases, and announcements of 
the Eclipse foundation, suggest that the constituents in its BOD are very stable ${ }^{15}$. Companies appoint their employees to seat in the BOD for a relative long time. From official press releases, the researcher could not find a single re-appointment within the study period. Thus, the researcher deems the percentage calculated using the 2006 data as valid.

Figure 2 shows the proportion of company employees in the OSSF's BOD. Figure 2 shows that company employees comprise $100 \%$ of the members of the BOD of Eclipse and Plone. The corresponding proportions for the other four foundations (SPI, Python, Apache, and GNOME) range between 52\% and $67 \%$.

\section{Figure 2: Proportion of company employees in BOD}

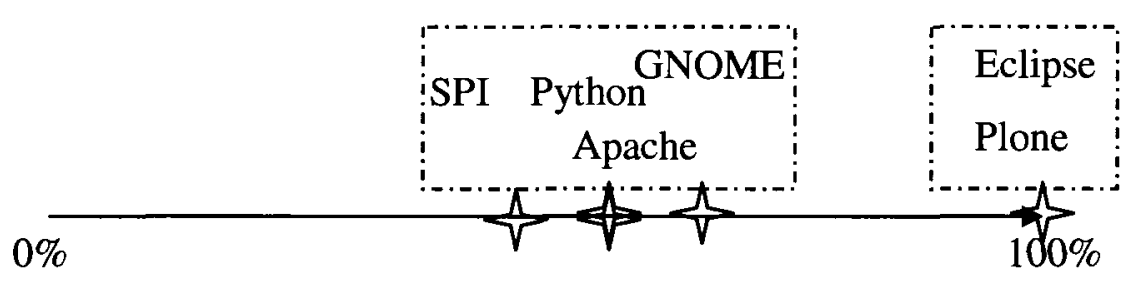

Figure 3 provides the proportion of employees from companies that do not depend on OSSF's projects for significant portion of revenue who are members of the BOD. This proportion can be used to cluster the six OSSFs into three groups. The first group has

\footnotetext{
15 The bylaw of Eclipse foundation states that the ratio of paid board members to meritocracy board members is around 6:1. Due to the nature of how BOD members are designated, its BOD members are very stable over the years.
} 
three OSSFs, SPI, Plone, and Apache. The second group is comprised of Python and GNOME. The third group includes one OSSF, Eclipse.

Figure 3: Proportion of employees in BOD from companies that do not depend on OSSF's projects for significant portion of revenue

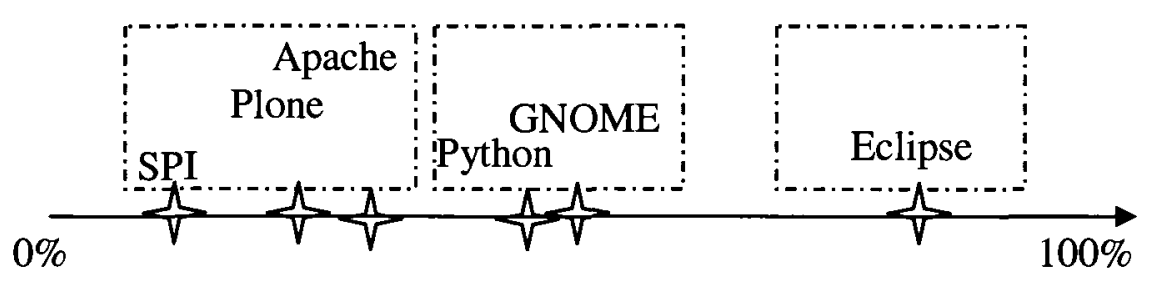

Table 10 shows the number and proportion of employees in the OSSF BOD who are part of companies' top management teams (TMT). 
Table 10: Employees in BOD who are part of TMT*

\begin{tabular}{|c|l|c|c|c|c|c|c|}
\hline IDN & \multicolumn{1}{|c|}{ Metrics } & Apache & Python & SPI & Plone & Eclipse & GNOME \\
\hline $1-1$ & Number of members of BOD & 27 & 21 & 29 & 16 & 31 & 33 \\
\hline $1-5$ & $\begin{array}{l}\text { Number of employees in BOD who } \\
\text { are part of companies' TMT }\end{array}$ & 10 & 5 & 3 & 10 & 17 & 7 \\
\hline $1-5-1$ & $\begin{array}{l}\text { Proportion of employees in BOD } \\
\text { who are part of companies' TMT }\end{array}$ & $37 \%$ & $24 \%$ & $11 \%$ & $63 \%$ & $55 \%$ & $24 \%$ \\
\hline $1-6$ & $\begin{array}{l}\text { Number of employees in BOD who } \\
\text { are part of TMT of companies that } \\
\text { do not depend on OSSF projects for } \\
\text { significant portion of revenue }\end{array}$ & 3 & 3 & 3 & 2 & 13 & 7 \\
\hline $1-6-1$ & $\begin{array}{l}\text { Proportion of employees in BOD } \\
\text { who are part of TMT of companies } \\
\text { that do not depend on OSSF } \\
\text { projects for significant portion of } \\
\text { revenue }\end{array}$ & $11 \%$ & $14 \%$ & $10 \%$ & $13 \%$ & $42 \%$ & $24 \%$ \\
\hline
\end{tabular}

* Apache, Python, and GNOME: 2004-2006; SPI: 2003-2005; Plone: 2005-2006; Eclipse: 2006

\subsubsection{Governance}

\section{Governance structure}

This section illustrates two aspects of the governance structure of OSSFs: (i) general information on membership structure of the OSSFs in the sample, and (ii) the dominate relation between BOD and members (Schnurbein, 2006). A nominal variable was developed to assess the degree to which a member can participate in decision making and influence the outcome. 
Table 11 compares the OSSFs in the sample using the information identified in governance documents (i.e., bylaw and charter). General information on membership structure includes metrics 2-1 to 2-4. Metric 2-5 to 2-15 are members' decision making rights, which to some extent shape the primary decision making of the BOD in an OSSF. Metrics 2-16 and 2-17 describe the rights of the members to be elected as the members of BOD, which is the major governance actor in OSSFs. 
Table 11: Participation in decision making

\begin{tabular}{|c|l|c|c|c|c|c|c|}
\hline IDN & \multicolumn{1}{|c|}{ Metrics } & Apache & Python & SPI & Plone & Eclipse $^{16}$ & GNOME \\
\hline $2-1$ & Member criteria & Meritocracy & $\begin{array}{l}\text { Meritocracy } \\
\text { Sponsorship }\end{array}$ & Meritocracy & Meritocracy & $\begin{array}{c}\text { Meritocracy } \\
\text { Sponsorship }\end{array}$ & $\begin{array}{c}\text { Meritocracy } \\
\text { Sponsorship }\end{array}$ \\
\hline $2-2$ & $\begin{array}{l}\text { Majority member by } \\
\text { number }\end{array}$ & Merit & Merit & Merit & Merit & Merit & Merit \\
\hline $2-3$ & Member constitution & Individual & $\begin{array}{l}\text { Individual } \\
\text { Organization }\end{array}$ & Individual & Individual & $\begin{array}{c}\text { Individual } \\
\text { Organization }\end{array}$ & $\begin{array}{c}\text { Individual } \\
\text { Organization }\end{array}$ \\
\hline $2-4$ & $\begin{array}{l}\text { Merit members have } \\
\text { voting rights? }\end{array}$ & Yes & Yes & Yes & Yes & Yes & Yes \\
\hline $2-5$ & $\begin{array}{l}\text { Merit members can } \\
\text { submit requirements? }\end{array}$ & Yes & Yes & Yes & Yes & Yes & Yes \\
\hline $2-6$ & $\begin{array}{l}\text { Merit members can } \\
\text { reject policies and } \\
\text { guidelines? }\end{array}$ & Yes & Yes & Yes & Yes & No & Yes \\
\hline $2-7$ & $\begin{array}{l}\text { Merit members can } \\
\text { reject modification to } \\
\text { bylaw? }\end{array}$ & Yes & Yes & Yes & Yes & Yes & Yes \\
\hline $2-8$ & $\begin{array}{l}\text { Merit members can } \\
\text { reject modification to } \\
\text { common vision? }\end{array}$ & Yes & Yes & Yes & Yes & Yes & Yes \\
\hline $2-9$ & $\begin{array}{l}\text { Merit members can } \\
\text { reject primary Human } \\
\text { resource decision? }\end{array}$ & Yes & Yes & Yes & Yes & No & Yes \\
\hline $2-10$ & $\begin{array}{l}\text { Sponsor members have } \\
\text { voting rights? }\end{array}$ & N/A & Yes & N/A & N/A & Yes & No \\
\hline $2-11$ & $\begin{array}{l}\text { Sponsor members can } \\
\text { submit requirements? }\end{array}$ & N/A & Yes & N/A & N/A & Yes & Yes \\
\hline Sponsor members can & N/A & Yes & N/A & No \\
\hline
\end{tabular}

${ }^{16}$ Eclipse Rights by Membership Category

http://www.eclipse.org/membership/become_a_member/How2Join\%20Eclipse\%20Rights\%20by\%20Membership\%20

Category.pdf 


\begin{tabular}{|c|l|c|c|c|c|c|c|}
\hline & $\begin{array}{l}\text { reject policies and } \\
\text { guidelines? }\end{array}$ & & & & & & \\
\hline $2-13$ & $\begin{array}{l}\text { Sponsor members can } \\
\text { reject modification to } \\
\text { bylaw? }\end{array}$ & N/A & Yes & N/A & N/A & Yes & No \\
\hline $2-14$ & $\begin{array}{l}\text { Sponsor members can } \\
\text { reject modification to } \\
\text { common vision? }\end{array}$ & N/A & Yes & N/A & N/A & Yes & No \\
\hline $2-15$ & $\begin{array}{l}\text { Sponsor members can } \\
\text { reject primary human } \\
\text { resource decision? }\end{array}$ & No & No & No & No & Yes & No \\
\hline $2-16$ & $\begin{array}{l}\text { Institutionalized } \\
\text { breakdown of merit vs } \\
\text { sponsor members in } \\
\text { BOD }\end{array}$ & N/A & $15 \%$ & N/A & N/A & $>80 \%$ & $0 \%$ \\
\hline $2-17$ & $\begin{array}{l}\text { Institutionalized } \\
\text { breakdown of merit vs } \\
\text { sponsor members in } \\
\text { advisory BOD }\end{array}$ & N/A & N/A & N/A & N/A & N/A & $100 \%{ }^{\text {I/ }}$ \\
\hline 2-16-1 & $\begin{array}{l}\text { Extent to which the } \\
\text { sponsor members can } \\
\text { participate in decision } \\
\text { making in an OSSF }\end{array}$ & Merit & $\begin{array}{c}\text { Merit } \\
\text { Dominated }\end{array}$ & Merit & Merit & Sponsor \\
Dominated & Dominated \\
\hline
\end{tabular}

The six OSSFs in the sample are membership based nonprofits. There are two types of memberships, meritocracy based and sponsorship based. A sponsor member can only be an organization, and a merit member can only be an individual. In three foundations (Apache, SPI, and Plone), there are no sponsor members.

${ }^{17}$ Nonprofits can be members of advisory board and exempt for membership fees. 
A nominal variable was used to represent the extent to which OSSF's bylaws allowed sponsor members to participate in decision making. The variable was allowed one of three values: "Sponsor Dominated", "Merit Dominated" or "Merit". The variable is "Sponsor Dominated" if the bylaws of the OSSF allowed sponsor members to hold a majority in the BOD. The variable is "Merit Dominated" if the bylaws of the OSSF: (i) allowed sponsor members to hold a minority position in the BOD but not a majority position or (ii) allowed sponsor members to hold positions in one or more Advisory BODs, but not on the BOD. The variable is "Merit" if the bylaws allowed merit members but not sponsor members.

The last row in Table 11 indicates that Apache, Plone, and SPI are "Merit" OSSFs. Their bylaws only allow merit members. They do not recognize sponsor members.

Python and GNOME are "Merit Dominated" OSSFs. The bylaws of Python provide sponsor and merit members with full voting rights. One organization that is a sponsor member has the same rights as an individual who is a merit member. Thus, the extent to which sponsor members can influence outcomes is low. The bylaws of GNOME do not allow sponsor members to be part of the BOD. They can only become members of the Advisory Board. Again, the extent to which sponsor members can influence outcomes is low.

Eclipse is a "Sponsor Dominated" OSSF. The Eclipse bylaws provide sponsor members with full voting rights and merit members with limited rights. Moreover, most merit 
members in Eclipse are company employees. Thus, company employees have a high level of participation in decision making.

Figure 4 illustrates the OSSFs categorized into three groups based on the nominal variable that represents the extent to which the sponsor members can participate in OSSF decision making.

Figure 4: Extent to which a sponsor member can participate in OSSF decision making

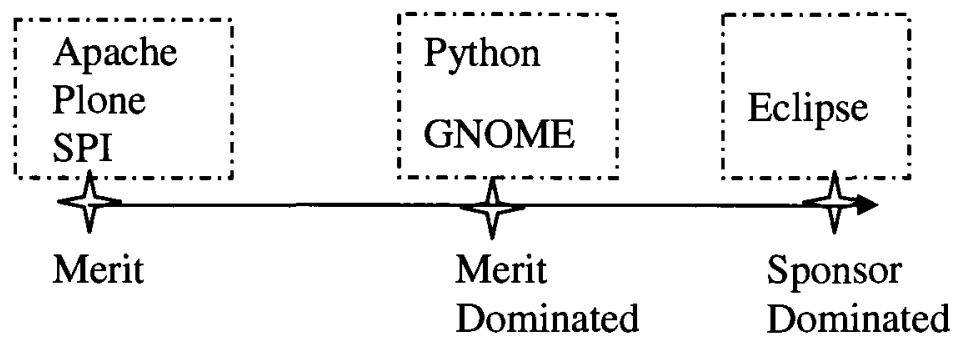

\section{BOD Composition}

This section provides the results regarding BOD members' reputation and occupation.

Table 12 shows the number of members of the BOD of OSSF whose name appeared in the list of celebrities prepared by Abrahamsen (2007). 
Table 12: Reputation in OSS community*

\begin{tabular}{|c|l|c|c|c|c|c|c|}
\hline IDN & \multicolumn{1}{|c|}{ Metrics } & Apache & Python & SPI & Plone & Eclipse & GNOME \\
\hline $1-1$ & Number of members of BOD & 27 & 21 & 29 & 16 & 31 & 33 \\
\hline $2-17$ & $\begin{array}{l}\text { Number of members of BOD } \\
\text { who have reputation in OSS } \\
\text { community }\end{array}$ & 5 & 2 & 6 & 0 & 0 & 1 \\
\hline $2-17-1$ & $\begin{array}{l}\text { Proportion of members of } \\
\text { BOD who have reputation in } \\
\text { OSS community }\end{array}$ & $19 \%$ & $10 \%$ & $21 \%$ & $0 \%$ & $0 \%$ & $3 \%$ \\
\hline
\end{tabular}

* Apache, Python, and GNOME: 2004-2006; SPI: 2003-2005; Plone: 2005-2006; Eclipse: 2006

Appendix 3 provides the rules for a name to be included in Abrahamsen's list as well as the list of celebrities assembled by Abrahamsen (2007).

Figure 5 illustrates the proportion of members of OSSFs' BOD who are celebrities in the OSS community.

Figure 5: Proportion of members of BOD who are celebrities in the OSS community

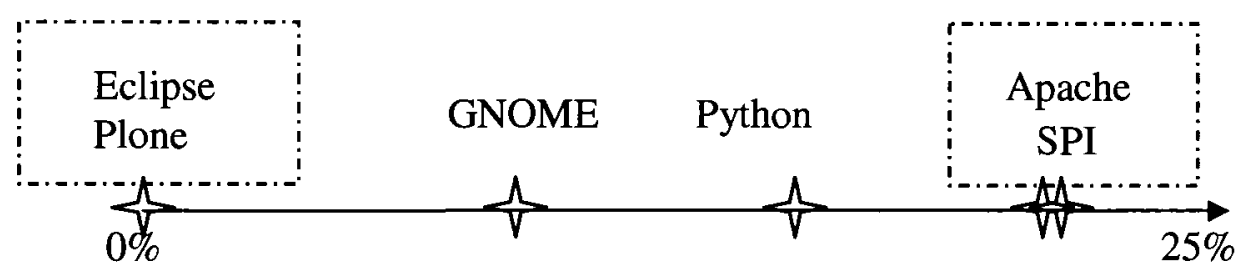


Table 13 provides the number and proportion of members of the BOD with different occupation and position in companies. These companies may not have a direct relationship with the open source projects.

Table 13: Occupation of BOD members ${ }^{*}$

\begin{tabular}{|c|c|c|c|c|c|c|c|}
\hline IDN & Metrics & Apache & Python & SPI & Plone & Eclipse & $\overline{\text { GNOME }}$ \\
\hline $1-1$ & Number of members of BOD & 27 & 21 & 29 & 16 & 31 & 33 \\
\hline $2-18$ & $\begin{array}{l}\text { Number of members of BOD } \\
\text { who are engineers or scientists }\end{array}$ & 12 & 12 & 18 & 3 & 4 & 15 \\
\hline $2-18-1$ & $\begin{array}{l}\text { Proportion of members of } \\
\text { BOD who are engineers or } \\
\text { scientists }\end{array}$ & $44 \%$ & $57 \%$ & $67 \%$ & $19 \%$ & $13 \%$ & $52 \%$ \\
\hline $2-19$ & $\begin{array}{l}\text { Number of members of BOD } \\
\text { who are managers }\end{array}$ & 3 & 1 & 0 & 2 & 2 & 2 \\
\hline $2-19-1$ & $\begin{array}{l}\text { Proportion of members of } \\
\text { BOD who are managers }\end{array}$ & $11 \%$ & $5 \%$ & $0 \%$ & $13 \%$ & $6 \%$ & $7 \%$ \\
\hline $2-20$ & $\begin{array}{l}\text { Number of members of BOD } \\
\text { who provide business, public } \\
\text { relation, legal, or strategy } \\
\text { services }\end{array}$ & 0 & 2 & 3 & 0 & 4 & 4 \\
\hline $2-20-1$ & $\begin{array}{l}\text { Proportion of members of } \\
\text { BOD who provide business, } \\
\text { public relation, legal, or } \\
\text { strategy services }\end{array}$ & $0 \%$ & $10 \%$ & $11 \%$ & $0 \%$ & $13 \%$ & $14 \%$ \\
\hline $2-21$ & $\begin{array}{l}\text { Number of members of BOD } \\
\text { who are part of companies' } \\
\text { TMT }\end{array}$ & 10 & 5 & 3 & 10 & 17 & 7 \\
\hline $2-21-1$ & $\begin{array}{l}\text { Proportion of members of } \\
\text { BOD who are part of } \\
\text { companies' TMT }\end{array}$ & $37 \%$ & $24 \%$ & $11 \%$ & $63 \%$ & $55 \%$ & $24 \%$ \\
\hline
\end{tabular}

* Apache, Python, and GNOME: 2004-2006; SPI: 2003-2005; Plone: 2005-2006; Eclipse: 
Potential skills can be deduced from BOD members' occupations and positions in their companies (Siciliano, 1990, 1996). Only the latest occupation and position of the members of the BOD during the research period was counted.

A BOD member was included in the engineer or scientist category if he/she was an engineer, senior engineer, researcher, senior researcher, or scientist. The manager category includes members of BOD with junior, intermediate, or senior level manager titles. The category for members of BOD who provide business, public relation, legal, or strategic service includes BOD members who are business developers, strategists, public relation developers, and lawyers. TMT includes BOD members who have top management team titles, such as VP, CEO, senior director, or president.

\section{Figure 6: Proportion of members of BOD who are engineers/scientists}

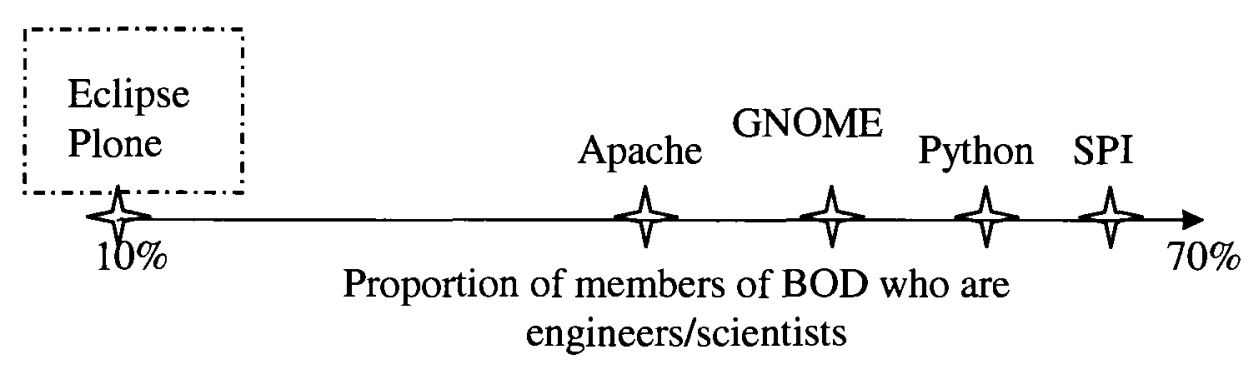

Figure 6 shows that the proportion of BOD members who are engineers and scientists between $13 \%$ and $67 \%$ and there are no natural clusters. 


\section{BOD's practice}

This section shows the governance activities carried out by the BOD of the OSSFs in the sample. Methods to carry out governance activities are compared among OSSFs in the sample. Differences in important governance policies are identified.

Table 14 provides a breakdown of all governance activates of BOD.

Table 14: Activity breakdown of OSSF BOD ${ }^{*}$

\begin{tabular}{|c|c|c|c|c|c|c|c|c|c|c|c|c|c|c|c|}
\hline IDN & Activities & \multicolumn{2}{|c|}{ Apache } & \multicolumn{2}{|c|}{ Python } & \multicolumn{2}{|c|}{ SPI } & \multicolumn{2}{|c|}{ Plone } & \multicolumn{2}{|c|}{ Eclipse } & \multicolumn{2}{|c|}{ GNOME } & \multicolumn{2}{|c|}{ All } \\
\hline & & $\#$ & $\%$ & \# & $\%$ & $\#$ & $\%$ & $\#$ & $\%$ & $\#$ & $\%$ & $\#$ & $\%$ & $\#$ & $\%$ \\
\hline $2-22$ & $\begin{array}{l}\text { Strategic } \\
\text { planning } \& \\
\text { common vision }\end{array}$ & 2 & $0 \%$ & 1 & $0 \%$ & 0 & $0 \%$ & 1 & $1 \%$ & 4 & $2 \%$ & 9 & $3 \%$ & 17 & $1 \%$ \\
\hline $2-23$ & $\begin{array}{l}\text { Policy \& } \\
\text { guideline }\end{array}$ & 50 & $8 \%$ & 47 & $23 \%$ & 21 & $34 \%$ & 36 & $20 \%$ & 39 & $23 \%$ & 45 & $13 \%$ & 238 & $15 \%$ \\
\hline $2-25$ & $\begin{array}{l}\text { Financial } \\
\text { governance }\end{array}$ & 26 & $4 \%$ & 24 & $12 \%$ & 12 & $20 \%$ & 14 & $8 \%$ & 9 & $5 \%$ & 29 & $9 \%$ & 114 & $7 \%$ \\
\hline $2-26$ & $\begin{array}{l}\text { Primary } \\
\text { resources } \\
\text { governance }\end{array}$ & 13 & $2 \%$ & 20 & $10 \%$ & 9 & $15 \%$ & 8 & $4 \%$ & 8 & $5 \%$ & 8 & $2 \%$ & 66 & $4 \%$ \\
\hline $2-27$ & $\begin{array}{l}\text { Human resource } \\
\text { governance }\end{array}$ & 6 & $1 \%$ & 0 & $0 \%$ & 0 & $0 \%$ & 11 & $6 \%$ & 5 & $3 \%$ & 3 & $1 \%$ & 25 & $2 \%$ \\
\hline $2-30$ & $\begin{array}{l}\text { BOD self } \\
\text { development }\end{array}$ & 1 & $0 \%$ & 6 & $3 \%$ & 3 & $5 \%$ & 6 & $3 \%$ & 1 & $1 \%$ & 5 & $1 \%$ & 22 & $1 \%$ \\
\hline $2-31$ & $\begin{array}{l}\text { Governance } \\
\text { structure } \\
\text { management }\end{array}$ & 22 & $3 \%$ & 12 & $6 \%$ & 4 & $7 \%$ & 32 & $18 \%$ & 26 & $15 \%$ & 34 & $10 \%$ & 130 & $8 \%$ \\
\hline $2-32$ & $\begin{array}{l}\text { Community } \\
\text { development }\end{array}$ & 12 & $2 \%$ & 5 & $2 \%$ & 0 & $0 \%$ & 10 & $6 \%$ & 28 & $17 \%$ & 8 & $2 \%$ & 63 & $4 \%$ \\
\hline $2-33$ & Conference & 16 & $2 \%$ & 20 & $10 \%$ & 0 & $0 \%$ & 2 & $1 \%$ & 8 & $5 \%$ & 55 & $16 \%$ & 101 & $6 \%$ \\
\hline & Total activities & 664 & $41 \%$ & 202 & $13 \%$ & 61 & $4 \%$ & 181 & $11 \%$ & 168 & $10 \%$ & 336 & $21 \%$ & 1612 & $100 \%$ \\
\hline
\end{tabular}

* Apache, Python, and GNOME: 2004-2006; SPI: 2003-2005; Plone: 2005-2006; Eclipse: 
Table 14 provides a count for each type of governance activity undertaken each month by the BOD.

The "Strategic planning \& common vision" category includes BOD activities, such as long term planning, strategic planning, common vision development, goal clarification, strategy development, and mission reinstating. Activities in "Policies \& guidelines" relate to policies or guides generating. Activities in "Project governance" include project status review, roadmap or release discussion, project coordination, bounty discussion. BOD activities in "Financial governance" include financial status and budget review, budgeting or granting. Financial governance activities do not include those related to fund-raising activities. "Primary resources" includes activities which are important for foundation and community day-to-day operations, such as server, broadband network access service, workflow software, and website maintenance and infrastructures related activities. Activities in "Human resource governance" include appointing officer, hiring staff, and so on. "Fund-raising" activities include activities such as funding plan, funding rising method development, funding status review, sponsor advocation and communication. Activities in "External relation" include collaboration with companies, other open source foundation, officially attending open source conference, and press releases instructed by BOD, and etc. Activities in "BOD self development" include activities related to develop and improve BOD skill and performance in foundation governance. "Governance structure management" includes activities such as committee setup, membership review, and etc. Activities in "Community development" include fostering local communities, pushing and sponsoring community events. Since BODs in OSSFs spend much time and 
efforts on open source "Conferences", which have various effects on fund-raising, external collaboration, and community development. These activities are classified into one group.

The data in Table 14 is skewed because Apache has many top-level projects and it reviews its project status every three months. Since reviewing the status for each project counts as one activity, the percentage of total activities reported in Table 14 is skewed. Table 15 provides the same data as what is in Table 14 with the project governance category removed. 
Table 15: Activity breakdown of OSSF BOD excluding the project governance category $^{*}$

\begin{tabular}{|c|c|c|c|c|c|c|c|c|c|c|c|c|c|c|c|}
\hline IDN & Activities & \multicolumn{2}{|c|}{ Apache } & \multicolumn{2}{|c|}{ Python } & \multicolumn{2}{|c|}{ SPI } & \multicolumn{2}{|c|}{ Plone } & \multicolumn{2}{|c|}{ Eclipse } & \multicolumn{2}{|c|}{ GNOME } & \multicolumn{2}{|c|}{ All } \\
\hline & & $\#$ & $\%$ & $\#$ & $\%$ & \# & $\%$ & $\#$ & $\%$ & \# & $\%$ & $\#$ & $\%$ & $\#$ & $\%$ \\
\hline $5-1$ & $\begin{array}{l}\text { Strategic } \\
\text { Planning \& } \\
\text { Common Vision }\end{array}$ & 2 & $1 \%$ & 1 & $1 \%$ & 0 & $0 \%$ & 1 & $1 \%$ & 4 & $3 \%$ & 9 & $3 \%$ & 17 & $2 \%$ \\
\hline $5-2$ & $\begin{array}{l}\text { Policy \& } \\
\text { Guideline } \\
\end{array}$ & 50 & $26 \%$ & 47 & $26 \%$ & 21 & $34 \%$ & 36 & $20 \%$ & 39 & $27 \%$ & 45 & $15 \%$ & 238 & $22 \%$ \\
\hline $2-25$ & $\begin{array}{l}\text { Financial } \\
\text { Governance }\end{array}$ & 26 & $14 \%$ & 24 & $13 \%$ & 12 & $20 \%$ & 14 & $8 \%$ & 9 & $6 \%$ & 29 & $9 \%$ & 114 & $11 \%$ \\
\hline $2-26$ & $\begin{array}{l}\text { Primary } \\
\text { Resources } \\
\text { Governance } \\
\end{array}$ & 13 & $7 \%$ & 20 & $11 \%$ & 9 & $15 \%$ & 8 & $4 \%$ & 8 & $6 \%$ & 8 & $3 \%$ & 66 & $6 \%$ \\
\hline $2-27$ & $\begin{array}{l}\text { Human resource } \\
\text { Governance }\end{array}$ & 6 & $3 \%$ & 0 & $0 \%$ & 0 & $0 \%$ & 11 & $6 \%$ & 5 & $3 \%$ & 3 & $1 \%$ & 25 & $2 \%$ \\
\hline $2-28$ & Fund-Raising & 25 & $13 \%$ & 19 & $10 \%$ & 2 & $3 \%$ & 15 & $8 \%$ & 0 & $0 \%$ & 33 & $11 \%$ & 94 & $9 \%$ \\
\hline $2-29$ & External Relation & 16 & $8 \%$ & 30 & $16 \%$ & 10 & $16 \%$ & 43 & $24 \%$ & 16 & $11 \%$ & 80 & $26 \%$ & 195 & $18 \%$ \\
\hline $2-30$ & $\begin{array}{l}\text { BOD Self } \\
\text { Development }\end{array}$ & 1 & $1 \%$ & 6 & $3 \%$ & 3 & $5 \%$ & 6 & $3 \%$ & 1 & $1 \%$ & 5 & $2 \%$ & 22 & $2 \%$ \\
\hline $2-\overline{31}$ & $\begin{array}{l}\text { Governance } \\
\text { Structure } \\
\text { Management } \\
\end{array}$ & 22 & $12 \%$ & 12 & $7 \%$ & 4 & $7 \%$ & 32 & $18 \%$ & 26 & $18 \%$ & 34 & $11 \%$ & 130 & $12 \%$ \\
\hline $2-32$ & $\begin{array}{l}\text { Community } \\
\text { Development }\end{array}$ & 12 & $6 \%$ & 5 & $3 \%$ & 0 & $0 \%$ & 10 & $6 \%$ & 28 & $19 \%$ & 8 & $3 \%$ & 63 & $6 \%$ \\
\hline $2-33$ & Conference & 16 & $8 \%$ & 20 & $11 \%$ & 0 & $0 \%$ & 2 & $1 \%$ & 8 & $6 \%$ & 55 & $18 \%$ & 101 & $9 \%$ \\
\hline & Total Activities & 189 & $18 \%$ & 184 & $17 \%$ & 61 & $6 \%$ & 178 & $17 \%$ & 144 & $14 \%$ & 309 & $29 \%$ & 1065 & $100 \%$ \\
\hline
\end{tabular}

* Apache, Python, and GNOME: 2004-2006; SPI: 2003-2005; Plone: 2005-2006; Eclipse: 2006

Figure 7 shows the OSSFs in the sample categorized by BOD's efforts dedicated to strategic planning and common vision development.

Figure 7: Proportion of BOD's efforts dedicated to strategic planning and common vision development

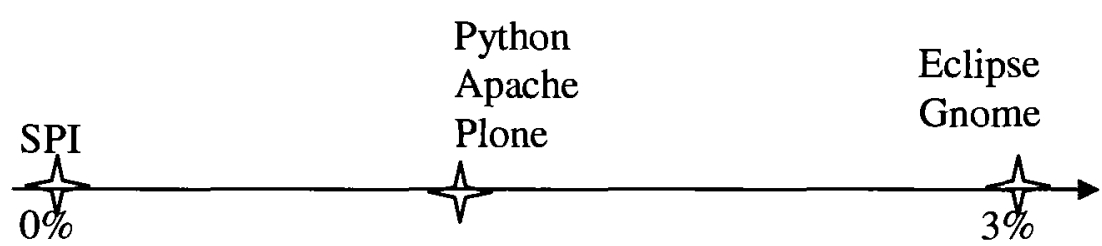


Table 16 shows the method used to carry out governance activities for the six OSSFs in the sample. In Eclipse, almost all the governance activities initiated by the BOD are carried out by externals. For the other five OSSFs in the sample, BOD members themselves undertake most of the activities related to management and operation.

Table 16: Method used to carry out governance activities

\begin{tabular}{|c|c|c|c|c|c|c|c|}
\hline IDN & Metrics & Apache & Python & SPI & Plone & GNOME & Eclipse \\
\hline $2-34$ & $\begin{array}{l}\text { Method to carry out } \\
\text { governance activities }\end{array}$ & \multicolumn{5}{|c|}{ By members of BOD or BOD committees } & $\begin{array}{l}\text { By authorizing } \\
\text { organizations or staffs } \\
\text { outside of BOD }\end{array}$ \\
\hline
\end{tabular}

Table 17 identifies differences in the primary policies and guidelines of the six OSSFs in the sample. 
Table 17: Difference in OSSF's primary policies and guidelines

\begin{tabular}{|c|c|c|c|c|c|c|c|}
\hline IDN & Metrics & Apache & Python & SPI & Plone & Eclipse & GNOME \\
\hline $2-35$ & $\begin{array}{l}\text { Existence of } \\
\text { umbrella policy }\end{array}$ & Yes & No & Yes & No & Yes & Yes \\
\hline $2-36$ & $\begin{array}{l}\text { Existence of } \\
\text { incubation policy }\end{array}$ & Yes & No & No & No & Yes & No \\
\hline $2-37$ & $\begin{array}{l}\text { Extent to which } \\
\text { committee of the } \\
\text { BOD has power } \\
\text { over roadmap }\end{array}$ & Independent & Independent & Independent & Strong & Strong & Strong \\
\hline $2-38$ & $\begin{array}{l}\text { Extent to which } \\
\text { committee of the } \\
\text { BOD has power } \\
\text { over release } \\
\text { schedule }\end{array}$ & Independent & Independent & Independent & Strong & Strong & Strong \\
\hline $2-39$ & $\begin{array}{l}\text { Restrictions on } \\
\text { commercial usage }\end{array}$ & $\begin{array}{l}\text { Can resale } \\
\text { No need to } \\
\text { contribute } \\
\text { back } \\
\text { No need to } \\
\text { open source } \\
\text { code }\end{array}$ & $\begin{array}{l}\text { Can resale } \\
\text { No need to } \\
\text { contribute } \\
\text { back } \\
\text { No need to } \\
\text { open source } \\
\text { code }\end{array}$ & $\begin{array}{l}\text { Need to } \\
\text { contribute } \\
\text { back } \\
\text { Need to } \\
\text { open source } \\
\text { code }\end{array}$ & $\begin{array}{l}\text { Need to } \\
\text { contribute } \\
\text { back } \\
\text { Need to } \\
\text { open } \\
\text { source } \\
\text { code }\end{array}$ & $\begin{array}{l}\text { Can resale } \\
\text { No need to } \\
\text { contribute } \\
\text { back } \\
\text { No need to } \\
\text { open source } \\
\text { code }\end{array}$ & $\begin{array}{l}\text { Need to } \\
\text { contribute } \\
\text { back } \\
\text { Need to } \\
\text { open } \\
\text { source } \\
\text { code }\end{array}$ \\
\hline
\end{tabular}

An OSSF is considered to be an umbrella foundation if its policy regulates it to host more than one major foundation project. Apache and Eclipse are foundations which have incubation policies to help new OSS projects grow.

A roadmap and release control policy is deemed to be controlled if: (i) final decisions are made by a committee of the BOD, rather by consensus or (ii) it is time based (Michlmayr, 2007). 
Figure 8 illustrates that the six foundations can be organized into two groups according to the extent to which a committee of the BOD has power over the timing and content of software roadmaps and releases. BOD committees in the Eclipse, GNOME and Plone foundations have strong control over software releases. This is not the case for the other three foundations.

Figure 8: Extent to which a committee of the BOD has power over the timing and content of software releases

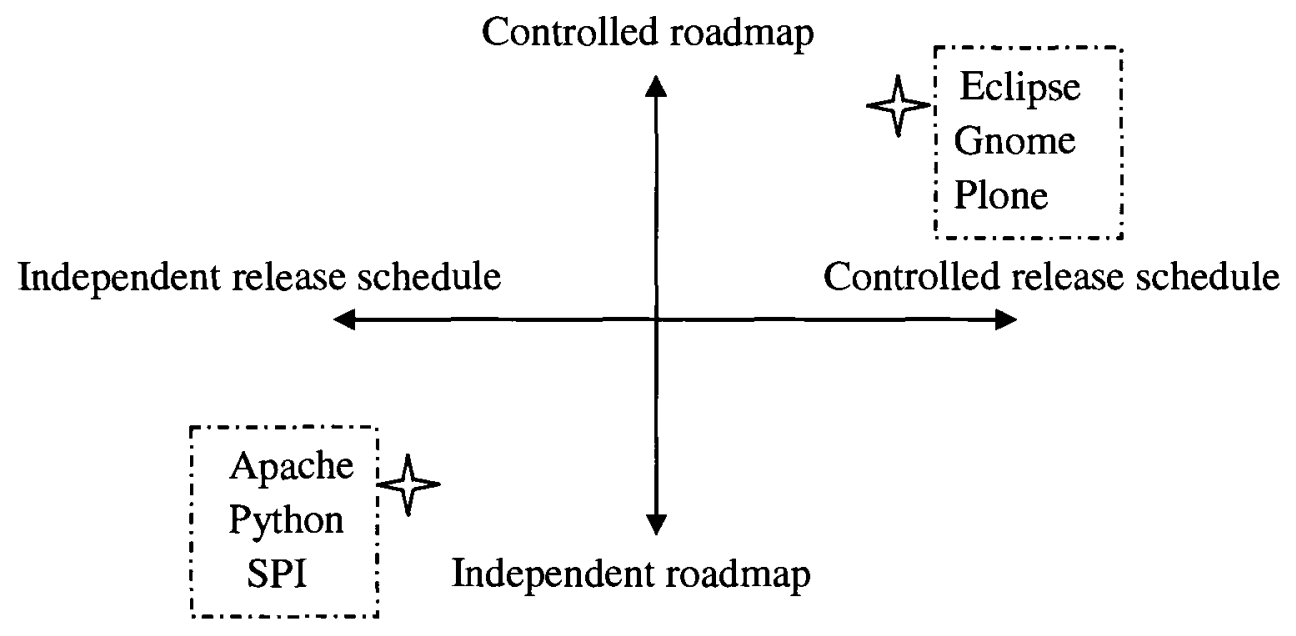

\subsubsection{Foundation effectiveness}

This section provides the result on OSSF effectiveness. Effectiveness metrics identified from official governance documents with data available are categorized into project effectiveness, community effectives, and resource effectiveness. OSSFs in the sample are compared based on their major sources of revenue. 
Continuous data on OSSF effectiveness is not readily available. Tables 19 to 21 extract data from Appendixes 4 to 6 . Revenue is the only metric with sufficient data to be included in this research as a measure of performance.

Table 18: Project effectiveness: number of projects in OSSFs

\begin{tabular}{|c|l|c|c|c|c|c|c|}
\hline \multicolumn{1}{|c|}{ Metrics } & \multicolumn{3}{|c|}{ Apache } & \multicolumn{3}{c|}{ SPI } \\
\hline \multicolumn{2}{|c|}{} & 2006 & 2005 & 2004 & 2005 & 2004 & 2003 \\
\hline $3-1$ & $\begin{array}{l}\text { Number of total projects } \\
\text { in foundation }\end{array}$ & 37 & 27 & 19 & 9 & 6 & 4 \\
\hline \multicolumn{2}{|l|}{} & \multicolumn{3}{|c|}{ GNOME } & \multicolumn{3}{c|}{ Eclipse } \\
\hline $3-1$ & $\begin{array}{l}\text { Number of total projects } \\
\text { in foundation }\end{array}$ & 2806 & 2005 & 2004 & 2006 & 2005 & 2004 \\
\cline { 2 - 8 } & & 182 & 122 & 66 & 50 & 33 \\
\hline
\end{tabular}

Table 19: Community effectiveness: number of foundation members (merit and sponsor)

\begin{tabular}{|c|l|c|c|c|c|c|c|c|c|c|}
\hline IDN & \multicolumn{1}{|c|}{ Metrics } & \multicolumn{3}{|c|}{ Apache } & \multicolumn{3}{c|}{ SPI } & \multicolumn{3}{c|}{ Plone } \\
\hline \multicolumn{2}{|l|}{} & 2006 & 2005 & 2004 & 2005 & 2004 & 2003 & 2006 & 2005 & 2004 \\
\hline $3-2$ & $\begin{array}{l}\text { Number of } \\
\text { members }\end{array}$ & 202 & 176 & 117 & 595 & 551 & 403 & 101 & 95 & N/A \\
\hline $3-3$ & Merit member & 202 & 176 & 117 & 595 & 551 & 403 & 101 & 95 & N/A \\
\hline \multicolumn{2}{|c|}{} & \multicolumn{3}{|c|}{ Python } & \multicolumn{3}{c|}{ GNOME } & \multicolumn{3}{c|}{ Eclipse } \\
\cline { 3 - 14 } & 2006 & 2005 & 2004 & 2006 & 2005 & 2004 & 2006 & 2005 & 2004 \\
\hline $3-2$ & Total member & 595 & 551 & 403 & 375 & 368 & 335 & 914 & 590 & 397 \\
\hline $3-3$ & Merit member & 102 & 92 & 83 & 360 & 354 & 324 & 765 & 470 & 316 \\
\hline $3-4$ & Sponsor member & 21 & 17 & 10 & 15 & 14 & 11 & 131 & 104 & 68 \\
\hline
\end{tabular}


Table 20: Resource effectiveness: financial effectiveness

\begin{tabular}{|c|c|c|c|c|c|c|c|c|c|c|}
\hline IDN & Metrics & \multicolumn{3}{|c|}{ Apache } & \multicolumn{3}{c|}{ Python } & \multicolumn{3}{c|}{ SPI } \\
\hline \multicolumn{2}{|c|}{} & 2006 & 2005 & 2004 & 2006 & 2005 & 2004 & 2006 & 2005 & 2004 \\
\hline $3-5$ & $\begin{array}{l}\text { Over all } \\
\text { revenue }\end{array}$ & 149121 & 49212 & 17045 & 217138 & 147582 & 37119 & 38545 & $<25000$ & $<25000$ \\
\hline \multicolumn{2}{|c|}{} & \multicolumn{3}{|c|}{ Plone } & \multicolumn{3}{c|}{ Eclipse } & \multicolumn{3}{c|}{ GNOME } \\
\cline { 2 - 12 } & 2006 & 2005 & 2004 & 2006 & 2005 & 2004 & 2006 & 2005 & 2004 \\
\hline $3-5$ & $\begin{array}{l}\text { Over all } \\
\text { revenue }\end{array}$ & 3118 & 3390 & 100600 & $5.5 \mathrm{M}$ & $3.9 \mathrm{M}$ & $1.5 \mathrm{M}$ & 157565 & 12000 & 164253 \\
\hline
\end{tabular}

Table 18 shows the number of projects which can be used to evaluate project effectiveness for umbrella OSSFs. Table 19 shows the numbers of merit and sponsor members which can be used to evaluate community effectiveness. Table 20 shows the financial data which can be used to evaluate resource effectiveness. Since Eclipse is not required to make its tax filing public, its financial data comes from its BOD meeting minutes. Data for the other five foundations come from tax documents filed annually.

Figure 9 shows that the six OSSFs in the sample can be categorized into three groups based on revenue.

\section{Figure 9: Revenue of OSSFs}

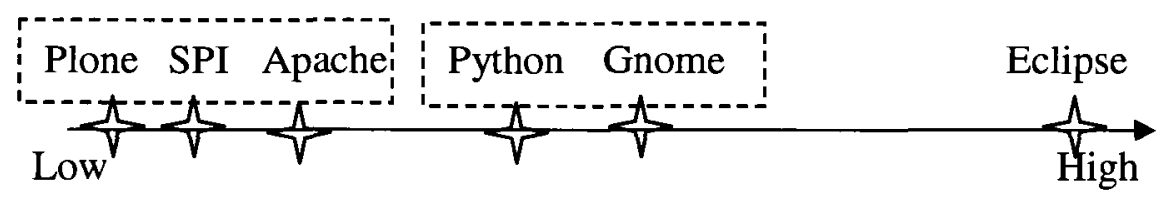


OSSFs can be categorized into three groups based on the main source of revenue. Table 21 shows that public donations were the major source of funding for Apache, SPI, and Plone. Python's major source of revenue is the Python conference. GNOME and Eclipse's major source of revenue is sponsor membership fees.

Table 21: Major revenue resources

\begin{tabular}{|c|c|c|c|c|c|}
\hline Apache & SPI & Plone & Python & GNOME & Eclipse \\
\hline \multicolumn{2}{|c|}{ Public donation } & Conference & Sponsor membership fees \\
\hline
\end{tabular}

\subsection{Model and propositions}

Figure 10 provides the model proposed by the researcher after examining the data and linking the categories founded earlier in this chapter. The model advances a relationship among company involvement, governance, and OSSF effectiveness. 


\section{Figure 10: Model for how company involvement and governance affect OSSF}

\section{effectiveness}

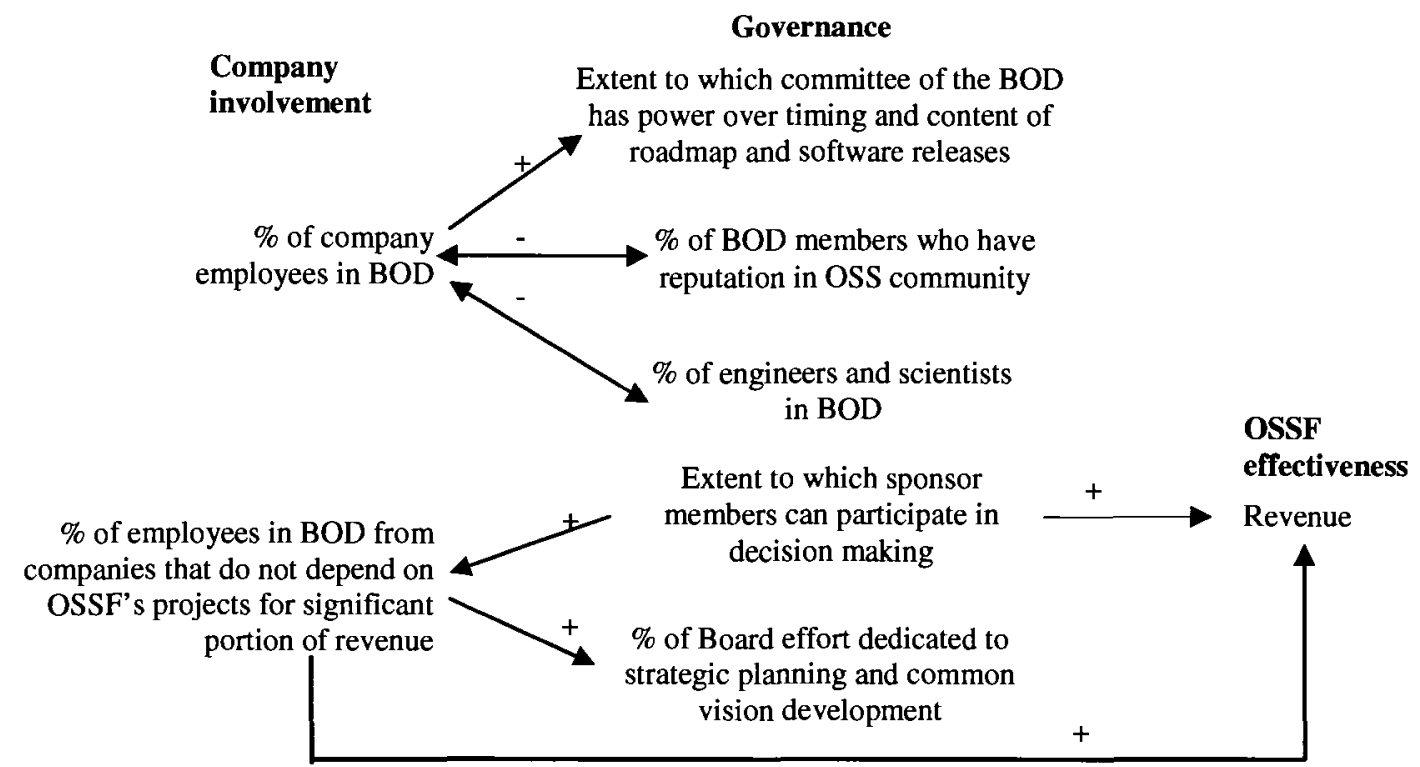

The model in Figure 10 indicates that the extent to which sponsor members can participate in decision making increases OSSF revenue. The model suggests that two metrics related to company involvement (the proportion of company employees in BOD and the proportion of employees in BOD from companies that do not depend on OSSF's projects for significant portion of revenue) are related to five metrics representing governance.

The Eclipse and Plone BOD are comprised exclusively of company employees (Figure 2), and have tight control over the software roadmap and releases (Figure 8). SPI, Apache, and Python BOD have the lowest proportion of BOD members who are company employees. These three BODs do not have high control over their roadmaps and software releases. For the Apache, SPI, member projects have independent roadmaps and software 
releases. Python's roadmap and release is controlled by a "benevolent dictator for life" (BDFL).

Based on the observations from Figures 2 and 8, the researcher proposed a causal relationship:

Proposition 1: Proportion of company employees in BOD positively affects the power of a committee of the BOD has over timing and content of roadmap software releases

Michlmayr (2007) reputed that one of the reasons that Plone has strict control over roadmap and software releases is that "many Plone developers work as consultants building web sites. Because of the unpredictability of Plone, it was difficult for them to decide which version to use for future projects". Generally, the business of companies generating revenues from open source software can benefit from predictable software release features. Thus, it is reasonable that companies will try to use their influence to make the development of open source software as predictable as possible. So, the researcher proposed that the proportion of company employees in BOD is a major contingent factor of extent to which committee of the BOD has power over timing and content of software releases and the relationship is a causal relationship.

Based on observations from Figures 2 and 5, the researcher proposed:

Proposition 2: The proportion of company employees in BOD is negatively related to the proportion of BOD members who have reputation in OSS community. 
For the two foundations which have the highest proportion of company employees in their BOD, Eclipse and Plone, there are no BOD members who have reputation in the OSS community. In contrast, SPI has the lowest proportion of company employees in BOD and the highest proportion of BOD members who have reputation in the OSS community. One possible explanation for this is that for those who have high reputation in OSS community, these kinds of people generally are traditional hackers, and are more likely to accept hacker ethos. Since the OSSFs with more company employees in BOD tends to have more control over roadmap and release schedule, people with high reputation in OSS community may deem it as a violation of hacker's ethos. It may be easier for individuals with a high reputation in the OSS community to obtain seats in BOD that is not dominated by company employees. Another possible explanation is that newly founded OSSFs are less likely to have prestigious celebrities, because there is less time for people in these foundations to develop a reputation. And since open source has attracted more businesses in recent years, newly founded OSSFs are more business driven and will tend to have more company employees in their BODs.

Based on observations from Figures 2 and 6, and Table 13, the researcher proposed:

Proposition 3: The proportion of company employees in BOD is negatively related to the proportion of engineers and scientists in BOD.

Company involvement in an OSSF BOD brings in business interests and decreases the extent that the OSSF is technology driven. The proportion of engineers and scientists in a 
BOD may reflect the extent to which the BOD is technology driven. Figures 2 and 6 show that the two foundations with the highest proportion of company employees in their BOD have the least proportion of engineers and scientists as members.

Based on observations from Figures 3 and 4, the researcher proposed a causal relationship:

Proposition 4: Extent to which sponsor members can participate in decision making positively affects the proportion of employees in BOD from companies that do not depend on OSSF's projects for significant portion of revenue.

When OSSFs provide mechanisms for company employees to participate in decision making as sponsor members, they attract a great number of individuals as members of BOD who are employed by companies that do not depend on OSSF's projects for significant portion of their revenue.

The proportion of employees in the OSSF BOD from companies that do not depend on OSSF's projects for significant portion of revenue is much larger than the proportion of sponsor members in the BOD (refer to Figure 3). Although companies are prescribed in the governance documents to become a sponsor member to hold their "voice" in OSSFs, they actually get more "voice" through their merit committers in OSSFs. For OSSFs which does not have sponsor members, the only way that companies can get involved in OSSFs is through merit members. 
Based on observations from Figures 3 and 7, the researcher proposed a causal relationship:

Proposition 5: Proportion of members of BOD from companies that do not depend on OSSF's projects for significant portion of revenue positively affect the proportion of BOD effort dedicated to strategic planning and common vision development.

Strategic planning and common vision development provide occasions for OSSFs to attain consensus on important issues. Company employees voice their companies' interests and try to align the interests of others with their own. For SPI, the researcher didn't find any sign of strategic planning and common vision development in the official BOD meeting minutes. For Apache, such activities are triggered by an external event, such as a license issue. Eclipse and GNOME are very active in activities related to strategic planning and common vision development.

The data suggests that OSSFs which have sponsor members are much more active than OSSFs which do not have sponsor members, in strategic planning and common vision development. Compared to Eclipses and GNOME, Python is not very active in strategic planning and share vision development. This may be explained by the fact that Python is engaged in programming language development.

Based on observations from Figures 6 and 9, and Table 21, the researcher proposes a causal relationship: 


\section{Proposition 6-a: Extent to which sponsor members can participate in decision making positively affects revenue of OSSFs.}

\section{Proposition 6-b: The proportion of employees in BOD from companies that do not depend on OSSF's projects for significant portion of revenue positively affects revenue of OSSFs.}

The researcher observed two positive associations: (i) association between the extent to which sponsor members can participate in decision making and revenue of OSSFs and (ii) association between the proportion of employees in BOD from companies that do not depend on OSSF's projects for significant portion of revenue and revenue of OSSFs. OSSFs with no sponsor members heavily rely on public donations, while OSSFs with sponsor members benefit from steady income from membership fees. Eclipse's revenue from membership fees are over 20 times greater than the revenue of the other OSSFs'. GNOME's membership fees are its major source of revenue. For Python, although its membership fees are not the major source of revenue, its revenue from its conference makes it the second richest OSSF. The extent to which sponsor members can participate in decision making attracts potential sponsors. Thus, it can positively affect revenue of OSSFs. The proportion of employees in BOD from companies that do not depend on OSSF's projects for significant portion of revenue reflects the degree of involvement of companies which have abundant resources, especially financial resource, to contribute to OSSFs. These companies have more will and ability to make monetary contribution to OSSFs. Thus, the researcher deemed that it can positively affect revenue of OSSFs. 


\section{DISCUSSION OF RESULTS}

This chapter is organized into three sections. Section 5.1 answers the four research questions. Section 5.2 provides observations on the relationship among company involvement, governance, and OSSF effectiveness deemed useful to executive directors of OSSFs, companies' top management teams, and academics. Section 5.3 links the results of this research with the literature reviewed in Chapter 2.

\subsection{Answers to research questions}

The first deliverable of this research was to answer the following four research questions:

(i) What are the different types of governance structures of OSSFs?

(ii) What are the practices of the BOD of OSSFs?

(iii) What is the composition of the BOD of OSSFs?

(iv) How do company involvement and governance affect OSSF effectiveness?

\subsubsection{Governance structure types}

Sponsor members join OSSFs as organizations while merit members join them as individuals. A sponsor member has one vote just as a merit member does. Bylaws clearly describe the rights of sponsor and merit members.

In this research, governance structure refers to "who participates in the decision-making". The data on the nominal variable: the extent to which the sponsor members can participate in the decision making of OSSFs in Table 12 and Figure 4, suggests that three 
governance types exist. The researcher has named the three types: (i) Merit; (ii) Merit Dominated; and (iii) Sponsor Dominated.

In foundations with a Merit type of governance structure, all members are merit members with full voting rights. In Merit Dominated governance structures, merit members are in a majority and it is difficult for sponsor members as a group to affect outcomes. In Sponsor Dominated governance structures sponsor members are in a majority. Sponsor members can be classified into tiers. Size of the payment determines tier membership. Merit members in Sponsor Dominated structures typically work for a company or research centre.

\subsubsection{BOD's practices}

Table 14 shows that twelve categories of governance activities are carried out by BODs of OSSFs. The twelve activity categories are: (i) strategic planning and common vision development; (ii) policy and guideline; (iii) project governance; (iv) financial governance; (v) primary resources governance; (vi) human resource governance; (vii) fund-raising; (viii) external relation management, (ix) BOD self development, (x) governance structure management, (xi) community development, and (xii) conference governance.

Table 14 indicates that all six BOD of the OSSFs in the sample allocate more than $60 \%$ of their effort carrying out activities that fall into the following four categories: (i) project governance (ii) policy and guidelines; (iii) external relations; and (iv) governance structure management. 
Table 14 also indicates that all six BOD of the OSSFs allocate the least amount of effort to carrying out activities that fall into the following three categories: (i) strategic planning and common vision development; (ii) human resource governance; and (iii) BOD self development.

That the BOD of the six OSSFs in the sample did not spend more effort raising funds was a surprise. The BOD of one foundation did not undertake activities to raise funds, and another only $3 \%$ of its activities were carried out to raise funds. Perhaps the reason for this is that OSSFs are mostly virtual organizations and large budgets are not required to operate them. Thus, the BODs of OSSFs do not carry out a large number of activities to raise funds.

The data in Table 14 suggests that the GNOME BOD is the most active (309 activities carried out), while that for SPI is the least active (61 activities carried out).

\subsubsection{BOD composition}

The occupation and status of BOD members affects the BOD's ability to carry out tasks as well as its behaviour and performance (Siciliano, 1990; Zald 1967; Pfeffer 1972; Baysinger \& Butler, 1985).

Table 13 shows the breakdown of BOD by occupation. It shows that Eclipse and Plone have a greater proportion of their BOD members with a background in management, 
business development, and strategic management. The proportion of engineers and scientists in their BOD are small. Table 13 shows that more than 50\% of the BOD of the Plone and Eclipse foundations are also part of companies' TMT.

SPI has the largest proportion of BOD members with engineer/scientist background (67\%) and a small proportion of BOD members with background in management, business development, and strategic management (11\%).

Table 12 indicates that the SPI and Apache foundations have the largest proportion of OSS celebrities in their BODs. Plone and Eclipse do not have a single OSS celebrity on their BOD.

\subsection{Model on how company involvement and governance affect OSSF effectiveness}

The model in Figure 10 is new. The inductive approach to model building was used. The model was developed from reasoning and observing information on the six foundations in the sample.

Figure 10 shows that company involvement is comprised of two dimensions: (i) company employees on the BOD and (ii) employees of companies that do not depend on OSSF's projects for significant portion of their revenue on the BOD. The latter dimension is a subset of the first.

In the model shown in Figure 10, OSSF governance is comprised of five dimensions. One 
dimension focuses on how much effort the BOD spends on strategic planning and common vision development. Two dimensions relate to the composition of the BOD: (i) BOD members who have a reputation in the OSS community and (ii) BOD members with a background in engineering and science. One dimension deals with power, specifically the power the BOD has over timing and content of roadmap and software releases and (ii) power of sponsor members. Finally, one dimension focuses on sponsor members' ability to participate in decision making.

The model in Figure 10 identifies revenue as the only variable that could be used to assess OSSF effectiveness in this research. Data for other variables were not available. It also shows that two dimensions, one that relates to company involvement and one that relates to governance, positively affect revenue.

The model highlights the importance of including on the BOD of OSSF employees of companies that do not depend on the OSSF's projects for significant portion of their revenue. The presence of these employees in the BOD increases the effort that BOD members will dedicate to strategic planning and common vision development as well as the OSSF's revenue.

Governance structure concurrently affects company involvement and OSSF revenue. This discovery is important for designing OSSFs. The greater the number of sponsor members in a BOD, the greater the number of employees of companies that do not depend on OSSF's projects for significant portion of their revenues and the greater the revenue. 
The model suggests that the number of company employees in a BOD is negatively correlated to the two BOD composition dimensions: (i) BOD members who have a reputation in the OSS community and (ii) BOD members with a background in engineering and science.

\subsection{Observations}

This section provides two observations on the relationship among company involvement, governance, and OSSF effectiveness deemed to be useful to executive directors of OSSFs, companies' top management teams, and academics.

The first observation is that OSSF with Sponsor Dominated governance structures register as 501(c)(6) nonprofits, while OSSFs with Merit and Merit Dominated structures register as 501(c)(3) nonprofits. Donations to 501(C)(6) OSSFs are not tax deductible to the donors. Thus, the public will not be interested in making donations to OSSFs registered as 501(c)(6). The 501(C)(6) OSSFs must attract revenue from membership fees to survive. OSSFs registered as 501(c)(3) OSSFs can receive at least one third of their support from the general public. Membership fees and revenues from OSS conferences are not deemed as support from the general public. Large donations from founders or BOD members, or going back year after year to the same foundations or corporations for income, may not count as "public" support ${ }^{18}$. From all the financial statement of sampled 501(c)(3) OSSFs, long term public support is generally below US $\$ 500,000$. This means,

${ }^{18}$ 501(c)3 Fact Sheet: http://www.rurdev.usda.gov/rbs/ezec/Toolbox/501c3factsheet.html 
that revenue for a 501(c)(3) OSSFs can not be much more than $\$ 150,000$ a year over the long run.

The second observation is on BOD's working styles. A BOD may delegate most of the managerial and operational activities to a full-time Executive Director or Chief Executive Officer and specific councils. This working style is consistent with that described by Carver (1996, 2001) as a "policy governing" BOD. A full-time management organization in the OSSF is the enabler for a "policy governing" BOD. For example, the BOD of the Eclipse Foundation can be referred to as a "policy governing" BOD.

The second working style refers to where BOD members, volunteers and staff members carry out the work of the BOD. This working style can be denoted "working" BOD.

\subsection{Links with the literature}

Weiss and Birnbaum (1989) examined technological infrastructures. These infrastructures were conceptualized as being comprised of a network of producers and users of technology anchored around a process and a dominant design. The characteristics of the technological infrastructures described by Weiss and Birnbaum (1989) seem to describe the infrastructures that Sponsor Dominated OSSFs provide companies to collaborate. It is less clear whether or not these characteristics describe the technological infrastructures established by Merit and Merit Dominated governance structures. 
The extant literature focuses on financial resources to assess the effectiveness of nonprofits (Provan, 1980; Pfeffer, 1973; Glisson \& Martin, 1980). Green and Griesinger (1996) argue that dimensions other than financial dimensions (e.g., revenue) should be used when measuring the effectiveness of nonprofits. While revenue data is the only data available (hence it was used as the only measure of effectiveness in this study), it may no be the best measure to assess OSSF's effectiveness. The reason for this may be that OSSFs are virtual organizations with less need for large budgets.

O'Mahony (2003) raises the concern of company involvement in OSSFs. The researcher, however, did not observe instances where company involvement negatively affected OSSF effectiveness.

Crowston et al. (2007) develop metrics, based on the features of SourceForge, to evaluate the effectiveness of open source software projects. Metrics identified to assess the effectiveness of the projects of OSSFs in this research are consistent with those used by Cowston et al. (2007), except for bug fixing time, which is not a concern of effectiveness in the official governance documents of the OSSFs in the sample.

While OSSFs are new phenomena, they share many characteristics with nonprofit organizations. This suggests that BOD members in OSSF can benefit from the literature on governance written for nonprofits (e.g. Houle, 1989; Slesinger, 1991; Carver, 1996, 2001; Gill et al., 2005). 


\section{CONCLUSIONS, LIMITATIONS, AND FUTURE RESEARCH}

This chapter is organized into three sections. Section 6.1 provides the main conclusions of this research. Section 6.2 describes the limitations of this research. Section 6.3 provides suggestions for future research.

\subsection{Conclusions}

The first conclusion is that OSSFs use at least three types of governance structures: Merit, Merit Dominated, and Sponsor Dominated.

The second conclusion is that we have an inductively constructed a model of the relationship among company involvement, governance and OSSF performance. The model in Figure 10 illustrates how company involvement improves OSSF governance and increases OSSF revenue and how governance also improves company involvement and affects revenue.

The third conclusion is that OSSF many not identify revenue as their most important measure of effectiveness. There is not enough data on OSSF effectiveness that is publicly available to carry out empirical research.

\subsection{Limitations}

This research has several limitations. First, as expected to be the case in exploratory studies of a new subject matter, the selection of constructs, dimensions, and metrics depends on the perspective of the researcher. Thus, this study inherits the limitations of 
inductive research.

Second, this research is limited because it did not examine indirect influence. Companies may exert their influence on OSSFs in indirect ways (i.e., ways other than assigning their employees to be part of OSSFs BOD).

Third, dimensions on OSSF effectiveness were identified by observing information on OSSF's official websites and governance documents. This approach does not provide insights that represent all of OSSF's stakeholders. Important effectiveness measures may not be discovered in this way. Surveys on effectiveness of OSSFs for GNOME and Eclipse foundations ${ }^{19}$ do exist. However, this data is not large enough to carry out research at this stage.

Fourth, the sample selection criteria led to the inclusion in the sample of well known, mature, US-based foundations. The selection criteria led to the elimination of important OSSFs such as Free Software Foundation, Perl foundation, FreeBSD foundation, OpenBSD foundation, and Gentoo foundation.

\subsection{Future research}

The following suggestions are made for future research:

The first suggestion is to empirically test the relationships identified in the model

${ }^{19}$ Eclipse started to do annual community since the end of 2006 
included as Figure 10.

The second suggestion for future research is to collect data from various OSSF stakeholders. Use a survey to examine how the various stakeholders assess OSSF effectiveness as the social constructivist approach suggests.

The third suggestion is to examine how company indirect influence affects the relationship among company direct influence, foundation governance, and foundation performance. 


\section{REFERENCE}

Abrahamsen, P. Free software celebrities according to google.

http://www.dina.kvl.dk/ abraham/free/fame.html. (Last accessed Novenber 1, 2007)

Alexander, J., \& Weiner, B. J. 1988. The adoption of the corporate governance model.

Nonprofit Management and Leadership, 8(3): 223-242.

Alvarado, E. I. 2000. Nonprofit or not-for-profit - Which are you? Nonprofit World, 18(6): 6-7.

Balser, D., \& McClusky, J. 2005. Managing stakeholder relationships and nonprofit organization effectiveness. Nonprofit Management and Leadership. 15(3): 295-315.

Baysinger, B. D., \& Butler, H. N. 1985. Corporate governance and the board of directors: Performance effects of changes in board composition. Journal of Law, Economics, and Organization, 1(1): 101-124.

Bies, A. L., \& Cowles, R. 2002. The Evolution of a review agency: Shaping contributing, or reflecting a shifting nonprofit organizational effectiveness and performance landscape? Paper presented at the Conference of Nonprofit Organizational Effectiveness and Performance, Midwest Center for Nonprofit Leadership, University of Missouri-Kansas City, Kansas City. 
Bonaccorsi, A. \& Rossi, C. 2004. Comparing motivations of individual programmers and firms to take part in the open source movement. From community to business. http://opensource.mit.edu/papers/bnaccorsirossimotivationlong.pdf. (Last accessed April 15, 2008)

Bradshaw, P., Murray V., \& Wolpin, J. 1992. Do nonprofit boards make a difference? An exploration of the relationships among board structure, process and effectiveness. Nonprofit and Voluntary Sector Quarterly, 21(3): 227-249.

Bradshaw, P., Hayday, B. Armstrong, R., Levesque, J., \& Rykert, L. 1998. Nonprofit governance models: Problems and prospects. Paper presented at the annual conference of the Association for Research on Nonprofit Organizations and Voluntary Action, Seattle.

Burlingame, D. 2004. Philanthropy in America: A comprehensive historical encyclopedia. Santa Barbara, CA: Abc-Clio Inc.

Cameron, K. 1986. Effectiveness as paradox: Consensus and conflict in conceptions of organizational effectiveness. Management Science, 32: 539-553.

Cameron, K., \& Whetten, D. 1983. Organizational effectiveness: A comparison of multiple models. New York: Academic Press. 
Capek, P. G., Frank, S. P., Gerdt, S., \& Shields, D. 2005. A history of IBM's open-source involvement and strategy. IBM System Journal, 44(2): 249-257.

Carver, J. 1996. Boards that make a difference: A new design for leadership in nonprofit and public organizations (2nd Ed.). San Francisco, CA: Jossey-Bass.

Carver, J. 2001. On board leadership. San Francisco, CA: Jossey-Bass.

Chait, R. P., Holland, T. P., \& Taylor, B. E. 1996. Improving the performance of governing boards. Phoenix, AZ: Oryx Press.

Crittenden, W. F., Crittenden, V. L., \& Hunt, T. G. 1988. Planning and stakeholder satisfaction in religious organizations. Journal of Voluntary Action Research, 17: 60-73.

Dayton, K. N. 1987. Governance is governance. Washington DC: Independent Sector.

Duca, D. J. 1996. Nonprofit boards: Roles, responsibilities, and performance. New York: Wiley.

Dueñas, J. C., Parada, G. H. A., Cuadrado, F., Santillán, M., \& Ruiz, J. L. 2007. Apache and Eclipse: Comparing open source project incubators. IEEE Software, 24(6): $90-98$. 
Fielding, R. T. 1999. Shared leadership in the Apache project. Communications of the ACM, 42(4): 42-43.

Fitzgerald, B. 2006. The transformation of open source software. MIS Quarterly, 30(3): $587-598$.

Forbes, D. P. 1998. Measuring the unmeasurable: Empirical studies of nonprofit organization effectiveness from 1977 to 1997. Nonprofit and Voluntary Sector Quarterly, 27(2): 183-202.

Gabriel, R. P., \& Goldman, R. 2005. Innovation happens elsewhere. San Fransisco, CA: Morgan Kaufmann Publishers.

Gill, M., Flynn, R. J., \& Reissing, E. 2005. The governance self-assessment checklist An instrument for assessing board effectiveness. Nonprofit Management and Leadership, 15(3): 271-294.

Glisson, C. A., \& Marin, P. Y. 1980. Productivity and efficiency in human service organizations as related to structure, size, and age. Academy of Management Journal, 23(1): $21-37$.

Green, J. C., \& Griesinger, D. 1996. Board performance and organizational effectiveness in social service organizations. Nonprofit Management and Leadership, 6(4): 
381-401.

Hawkins, R.E. 2004. The economics of open source software for a competitive firm: Why give it free? Netnomics, 6: 103-117.

Hecker, F. 1999. Setting up shop: The business of open-source software. IEEE Software, $16(1): 45-51$.

Helander, N., Aaltonen, T., Mikkonen, T., Oksanen, V., Puhakka, M., Seppänen, M., Vadén, T., \& Vainio, N. 2007. Open source software management framework, eBRC Research Reports 38,Tampere 2007. http://www.coss.fi/c/document_library/get_file?folderId=31\&name=DLFE-120.pdf (Last accessed November 18, 2007)

Henkel, J. 2003. Open source software from commercial firms - Tools, complements, and collective invention. http://www.inno-tec.bwl.uni-muenchen.de/forschung/henkel/OSS JHenkel 2003-05. pdf. (Last accessed November 18, 2007)

Herman, R. D. 1990. Methodological issues in studying the effectiveness of nongovernmental and nonprofit organizations. Nonprofit and Voluntary Sector Quarterly, 19 (3): 293-306. 
Herman, R. D., \& Heimovics, R. 1991. Executive leadership in nonprofit organizations: New strategies for shaping executive-board dynamics. San Francisco, CA: Jossey-Bass.

Herman, R. D., \& Renz, D. O. 1997. Multiple constituencies and the social construction of nonprofit organization effectiveness. Nonprofit and Voluntary Sector Quarterly, 26(2): 185-206.

Herman, R. D., \& Renz, D. O. 2000. Board practices of especially effective and less effective local nonprofit organizations. American Review of Public Administration, 30(2): 146-160.

Herman, R. D., Weaver, E., \& Heimovics, R. 1991. Judgments of nonprofit organization effectiveness. Presented at the annual meeting of the Association for Research on Nonprofit Organizations and Voluntary Action, Chicago.

Hodgkin, C. 1993. Policy and paper clips: Rejecting the lure of the corporate model. Nonprofit Management and Leadership, 3(4): 415-428

Hope, J. 2003. Open source as a business approach. Research School of Social Sciences, Australian National University, Canberra. http://rsss.anu.edu.au/ janeth/OSBusMod.html\#d8. (Last accessed April 15, 2008) 
Houle, C. O. 1989. Governing boards: Their nature and nurture. San Francisco, CA: Jossey-Bass.

Hult, K. M., \& Walcott, C. E. 1990. Governing public organizations: Politics, structures, and institutional design. Pacific Grove, CA: Brooks/Cole.

Kanter, R., \& Summers, D. 1987. Doing well while doing good: Dilemmas of performance measurement in nonprofit organizations and the need for a multiple-constituency approach. In W.W. Powell (Ed.), The nonprofit sector: $A$ research handbook. New Haven, CT: Yale University Press.

Kidane, Y. H., \& Gloor, P. A. 2007. Correlating temporal communication patterns of the Eclipse open source community with performance and creativety. Computational \& Mathmatical organization theory, 13(1): 17-27.

Koenig, J. 2004. Seven open source business strategies for competitive advantage. IT Manager's Journal, May 14.

Kushner, R. J., \& Poole, P. 1996. Exploring structure-effectiveness relationships in nonprofit arts organizations. Nonprofit Management and Leadership, 7(2): 119-136.

Lattemann, C., \& Stieglitz, S. 2005. Framework for governance in open source communities. Proceedings of the 38th Hawaii International Conference on System Sciences, Hawaii. 
Lerner, J., \& Tirole, J. 2001. The open source movement: Key research questions. European Economic Review, 45(4): 819-826.

Lerner, J., \& Tirole, J. 2002. Some simple economics of open source. Journal of Industrial Economics, 50(2): 197-234.

Markus, M. L., Manville, B., \& Agres, C. E. 2000. What makes a virtual organization work? Sloan Management Review, 42(1): 13-25.

McClusky, J. E., 2002 Re-thinking nonprofit organization governance: Implications for management and leadership. International Journal of Public Administration, 25(4): $539-559$

Michlmayr, M. 2007. Quality improvement in volunteer free and open source software projects: Exploring the impact of release management. $\mathrm{PhD}$ dissertation, University of Cambridge, Cambridge.

Mockus, A., Fielding, R. T., \& Herbsleb, J. 2000. A case study of open source software development: The Apache server. Presented at $22^{\text {nd }}$ International Conference on Software Engineesing, Limerick, Ireland.

Mockus, A., Fielding, R. T., \& Herbsleb, J. 2002. Two case studies of open source 
software development: Apache and Mozilla. ACM Transactions on Software Engineering and Methodology, 11(3): 309-346.

Murray, V., Bradshaw, P., \& Wolpin, J. 1992. Power in and around nonprofit boards: A neglected dimension of governance, Nonprofit Management and Leadership, 3(2): 165-182.

Nissila, J. 2004. Towards a better understanding of open source business models. http://w3.msi.vxu.se/users/per/IRIS27/iris27-1202.pdf. (Last accessed April 15, 2008)

O'Mahony, S. 2003a. Guarding the commons: How community managed software projects protect their work. Research Policy, 32(7): 1179-1198.

O'Mahony, S. 2003b. Non-profit foundations and their role in community-firm software collaboration. Sebastopol, CA: O'Reilly \& Associate.

O'Mahony, S., West, J. 2004. Contrasting organic and synthetic approaches to building technical communities. Paper presented at the Conference of Western Academy of Management, Las Vegas.

Pettigrew A., \& Mcnulty, T. 1995. Power and influence in and around the boardroom. Human Relations, 48(8): 845-873.

Pfeffer, J. 1973. Size, composition, and foundation of hospital boards of directors: A 
study of organization-environment linkage. Administrative Science Quarterly, 18(3): 349-363.

Provan, K. 1980. Board power and organizational effectiveness among human service agencies. Academy of Management Journal, 23(2): 221-236.

Roberts, J., Hann, I., \& Slaughter, S. 2006. Understanding the motivations, participation and performance of open source software developers: A longitudinal study of the apache projects. Marshall School of Business Working Paper No. IOM 01-06.

Rosenkopf, L. A. M., \& George, V. P. 2001. From the bottom up? Technical committee activity and alliance formation. Administrative Science Quarterly, 46(4): 748-772.

Saidel, J. R. 1998. Expanding the governance construct: functions and contributions of nonprofit advisory groups. Nonprofit and Voluntary Sector Quarterly, 27(4): 421-436.

Schmid, H. 2002. Relationships between organizational properties and organizational effectiveness in three types of nonprofit human service organizations. Public Personnel Management, 31(3): 377-395.

Schnurbein, G. V. 2006. Governance in trade associations and unions. Paper presented at the 7 th International Conference of the International Society for Third Sector 
Research (ISTR), Bangkok.

Siciliano, J. (1990). Strategic management and the board of directors: A survey of YMCA organizations in the eastern U.S. and Canada. Unpublished paper, University of Massachusetts.

Siciliano, J. I. 1996. The relationship of board member diversity to organizational performance. Journal of Business Ethics, 15: 1313-1320.

Siciliano, J. I. 1997. The relationship between formal planning and performance. Nonprofit Management and Leadership, 7(4): 387-404.

Spiller, D. \& Wichmann, T. 2002. Basics of open source software markets and business models. In Free/Libre and Open Source Software: Survey and Study. International Institute of Infonomics, Berlecom Research GmbH, Berlin.

http://www.berlecon.de/studien/downloads/200207FLOSS Basics.pdf. (Last accessed April 15, 2008)

Smith, D. H., \& Shen, C. 1996. Factors characterizing the most effective nonprofits managed by volunteers. Nonprofit Management and Leadership, 6(3): 271-289.

Slesinger, L. H. 1991. Self-assessment for nonprofit governing boards. Washington DC: National Center for Nonprofit Boards. 
Spear, R. 2004. Governance in democratic member-based organization. Annals of Public Cooperative Economics. 75(1): 33-59.

Taylor, M. E., \& Sumariwalla, R. D. 1993. Evaluating nonprofit effectiveness: Overcoming the barriers. In D. Young (Ed.), Governing, leading, and managing nonprofit organizations: New insights from research and practice, 93-116. San Francisco, CA: Jossey-Bass.

West, J. 2003. How open is open enough? Melding proprietary and open source platform strategies. Research Policy, 32(7): 1259-1285.

West, J., \& Gallagher, S. 2006. Challenges of open innovation: the paradox of firm investment in open source software. R\&D Management, 36(3): 315-328.

West, J., \& O'Mahony, S. 2005. Contrasting community building in sponsored and community founded open source projects. Proceeding of the 38th Hawaii International Conference, Hawaii.

Weiss, A. R., \& Birnbaum, P. H. 1989. Technological infrastructure and the implementation of technological strategies. Management Science, 35(8): 1014-1026.

Wichmann, T. 2002. Firms' open source activities: Motivations and policy implications. 
In Free/Libre and Open Source Software: Survey and Study, FLOSS Final Report. International Institute of Infonomics, Berlecom Research GmbH, Berlin. http://www.berlecon.de/studien/downloads/200207FLOSS Activities.pdf. (Last accessed April 15, 2008)

Widmer, C., \& Houchin, S. 1997. Governance of national federated organizations. Paper presented at the annual conference of the Association for Research on Nonprofit Organizations and Voluntary Action, Indianapolis, Indiana.

Wolf, T. 1984. The nonprofit organization: An operating manual. Saddle River, NJ: Prentice Hall. 


\section{LIST OF APPENDICES}

\section{Appendix 1: Sample selection}

\begin{tabular}{|c|c|c|c|c|c|}
\hline No & Foundation Name & $\begin{array}{l}\text { US } \\
501(c) ?\end{array}$ & $\begin{array}{l}\text { Active } \\
\text { software } \\
\text { project? }\end{array}$ & $\begin{array}{l}\text { Financial and } \\
\text { governance } \\
\text { records for } \\
\text { two years? }\end{array}$ & $\begin{array}{l}\text { Include in the } \\
\text { sample? }\end{array}$ \\
\hline 1 & Apache Software Foundation & Yes & Yes & Yes & Yes \\
\hline 2 & Eclipse Foundation & Yes & Yes & Yes & Yes \\
\hline 3 & Free Software Foundation & Yes & No & No & No \\
\hline 4 & FreeBSD Foundation & Yes & Yes & No & No \\
\hline 5 & GNOME Foundation & Yes & Yes & Yes & Yes \\
\hline 6 & Jabber Software Foundation & Yes & Yes & No & No \\
\hline 7 & Krysalis Foundation & No & - & - & No \\
\hline 8 & The Linux Foundation & Yes & No & - & No \\
\hline 9 & Mambo Foundation & No & - & - & No \\
\hline 10 & Mozdev Community Organization & Yes & Yes & No & No \\
\hline 11 & Mozilla Foundation & Yes & Yes & No & No \\
\hline 12 & NetBSD Foundation & Yes & Yes & No & No \\
\hline 13 & Open Bioinformatics Foundation & No & - & - & No \\
\hline 14 & Open Channel Foundation & No & - & - & No \\
\hline 15 & Open Security Foundation & No & - & - & No \\
\hline 16 & $\begin{array}{l}\text { Open Source Applications } \\
\text { Foundation }\end{array}$ & Yes & Yes & No & No \\
\hline 17 & $\begin{array}{l}\text { Open Source Geospatial } \\
\text { Foundation }\end{array}$ & No & - & - & No \\
\hline 18 & Open Source Initiative & Yes & No & - & No \\
\hline 19 & $\begin{array}{l}\text { Perl Foundation/Yet Another } \\
\text { Society }\end{array}$ & Yes & Yes & No & No \\
\hline 20 & Plone Foundation & Yes & Yes & Yes & Yes \\
\hline 21 & Python Software Foundation & Yes & Yes & Yes & Yes \\
\hline 22 & Radioactive Foundation & No & - & - & No \\
\hline 23 & Sakai Foundation & Yes & Yes & No & No \\
\hline 24 & Software In The Public Interest & Yes & Yes & Yes & Yes \\
\hline 25 & \begin{tabular}{|l} 
Wikimedia Foundation \\
\end{tabular} & Yes & No & - & No \\
\hline 26 & $\begin{array}{l}\text { X.Org Foundation } \\
\end{array}$ & Yes & Yes & No & No \\
\hline 27 & Xiph.Org & Yes & Yes & No & No \\
\hline 28 & Zope Foundation & No & - & - & No \\
\hline
\end{tabular}




\begin{tabular}{|l|l|c|c|c|c|}
29 & Blender & No & - & - & No \\
\hline 30 & Worldvista & Yes & Yes & No & No \\
\hline
\end{tabular}




\section{Appendix 2: Dimensions and metrics drawn from the data}

\begin{tabular}{|c|c|c|c|}
\hline Domain & Construct & Dimension & Metric \\
\hline \multirow[t]{4}{*}{$\begin{array}{l}\text { Company } \\
\text { involvement }\end{array}$} & \multirow[t]{2}{*}{$\begin{array}{l}\text { Company } \\
\text { investment }\end{array}$} & Resource investment & $\begin{array}{l}\text { - } \quad \text { Money invested } \\
\text { - Value of software contributed } \\
\text { - Value of hardware contributed } \\
\text { - Value of other resources contributed }\end{array}$ \\
\hline & & $\begin{array}{l}\text { Manpower } \\
\text { investment }\end{array}$ & $\begin{array}{l}\text { - Number of company employees in committers } \\
\text { - Number of company employees in OSSF members } \\
\text { - Number of company employees in committees and } \\
\text { councils } \\
\text { - Number of company employees in BOD } \\
\text { - Number of employees in BOD who are part of } \\
\text { companies' top management teams }\end{array}$ \\
\hline & \multirow[t]{2}{*}{$\begin{array}{l}\text { Company } \\
\text { influence }\end{array}$} & $\begin{array}{l}\text { BOD member's } \\
\text { prestige }\end{array}$ & $\begin{array}{l}\text { - Number of members of BOD who have reputation in } \\
\text { OSS community }\end{array}$ \\
\hline & & Employment & $\begin{array}{l}\text { - Number of company employees in BOD } \\
\text { - Number of employees in BOD from companies that } \\
\text { do not depend on OSSF's projects for significant } \\
\text { portion of revenue } \\
\text { - Number of employees in BOD who are part of top } \\
\text { management teams of companies that do not depend } \\
\text { on OSSF projects for significant portion of revenue } \\
\text { - Number of employees in BOD who are part of } \\
\text { companies' top management teams } \\
\text { Number of BOD's members who work for major } \\
\text { sponsor companies }\end{array}$ \\
\hline Governance & $\begin{array}{l}\text { Governance } \\
\text { structure }\end{array}$ & $\begin{array}{l}\text { Participation in } \\
\text { decision making }\end{array}$ & $\begin{array}{l}\text { - Member criteria } \\
\text { - Majority member by number } \\
\text { - Member constitution } \\
\text { - Whether or not merit members have voting rights } \\
\text { - Whether or not merit members can submit } \\
\text { - } \text { requirements }\end{array}$ \\
\hline
\end{tabular}




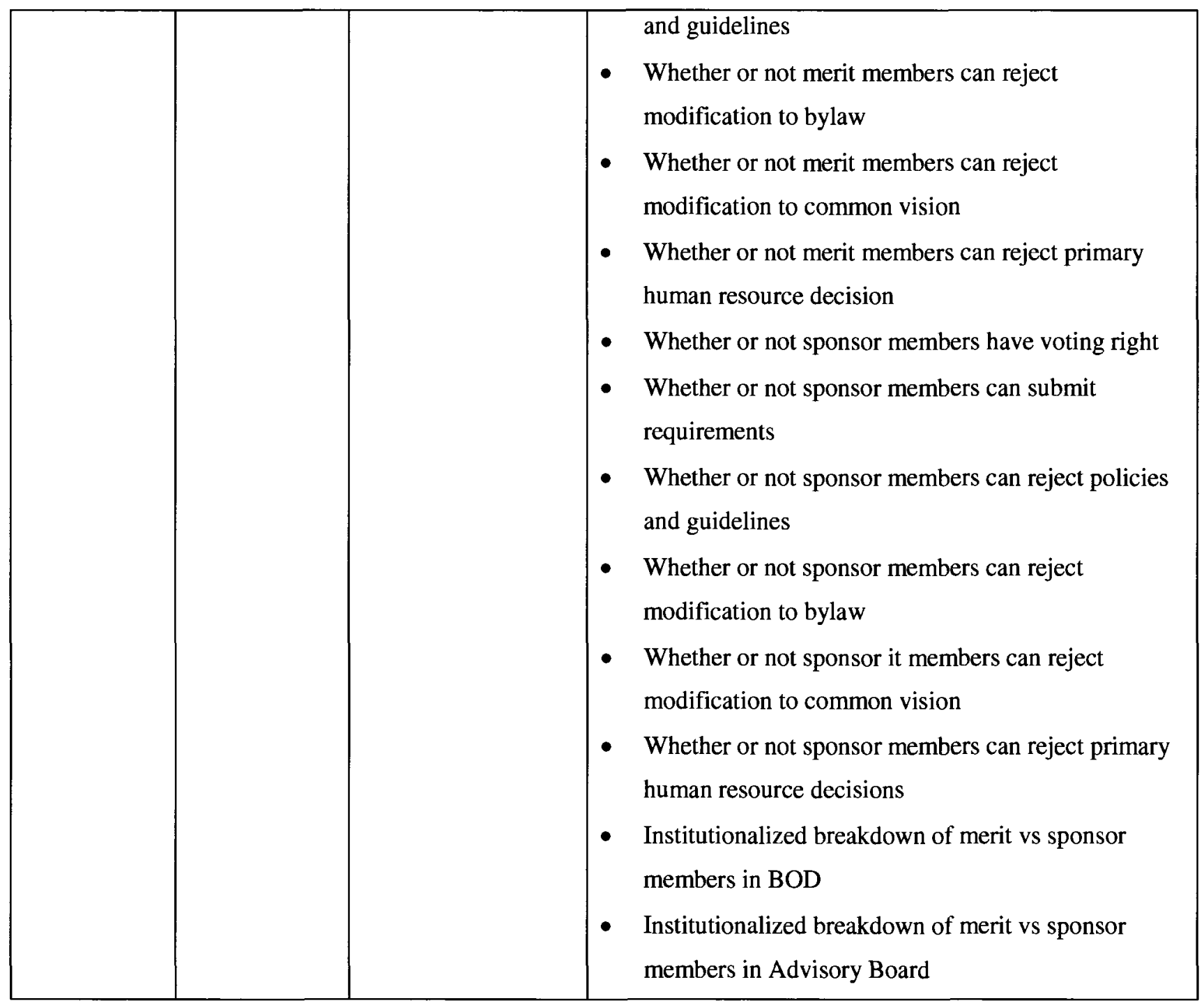




\begin{tabular}{|c|c|c|c|}
\hline & $\begin{array}{l}\text { BOD's } \\
\text { practices }\end{array}$ & Activities & $\begin{array}{l}\text { Proportion of BOD effort dedicated to: } \\
\text { - } \quad \text { strategic planning and common vision development } \\
\text { - } \quad \text { establishing policies and guidelines } \\
\text { - } \quad \text { project governance } \\
\text { - } \quad \text { financial governance } \\
\text { - } \quad \text { primary resources governance } \\
\text { - } \quad \text { human resource governance } \\
\text { - } \quad \text { fund raising } \\
\text { - } \quad \text { external relations } \\
\text { - } \quad \text { BOD self development } \\
\text { - } \quad \text { governance structure management } \\
\text { - } \quad \text { community development } \\
\text { - } \quad \text { conference planning and delivery } \\
\text { Method to carry out governance activities } \\
\text { - } \quad \text { Method to carry out governance activities } \\
\text { Content of important policies } \\
\text { - } \quad \text { Existence of umbrella policy } \\
\text { - } \quad \text { Existence of incubation policy } \\
\text { - } \quad \text { Extent to which committee of the BOD has power } \\
\text { - } \text { over roadmap } \\
\text { - } \text { Restrictiont to which committee of the BOD has power } \\
\text { over release schedule } \\
\text { - }\end{array}$ \\
\hline & $\begin{array}{l}\text { Composition } \\
\text { of BOD }\end{array}$ & $\begin{array}{l}\text { Prestige of BOD } \\
\text { member }\end{array}$ & $\begin{array}{l}\text { - Number of members of BOD who have a reputation } \\
\text { in OSS community }\end{array}$ \\
\hline & & Occupation & $\begin{array}{l}\text { - Number of members of BOD } \\
\text { - Number of members of BOD who are } \\
\text { engineers/scientists } \\
\text { - Number of members of BOD who are managers } \\
\text { - Number of members of BOD who provide business, } \\
\text { public relation, legal, or strategy services } \\
\text { - Number of members of BOD who are part of } \\
\text { companies' top management teams }\end{array}$ \\
\hline Effectiveness & Goal & Project effectiveness & - Number of total projects operated by OSSF \\
\hline
\end{tabular}




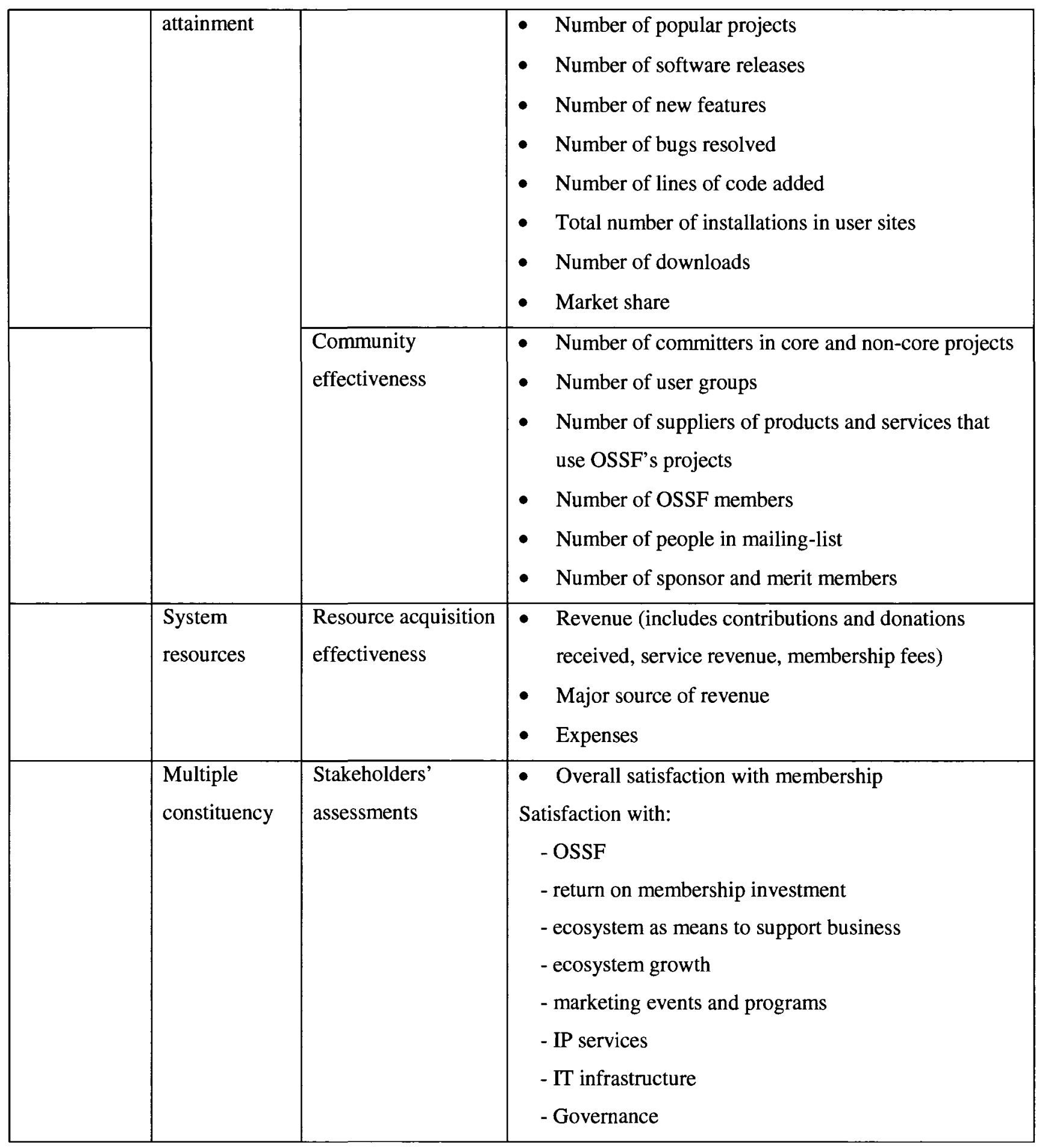




\section{Appendix 3: Prestige and reputation}

Abrahamsen (2007) generated a list of open source/free software celebrities using the number of Google hits.

The rules for a name to be included on the list are:

(i) The number of hits you obtain when searching for the name with Google must be

higher than the currently lowest placed name. The name should be surrounded in double quotes when entered into the search utility

(ii) The hits should be dominated by a single person

(iii) The hits should be dominated by free software references

(iv) Name variations are handled with the OR operator in Google

(v) Any questionable cases are decided by the list maintainer

The list of celebrities is:

\begin{tabular}{|c|l|c|l|}
\hline Rank & Name & Google hits & Project \\
\hline 1 & Linus Torvalds & 1600000 & Linux \\
\hline 2 & Richard M. Stallman & 1140000 & GNU \\
\hline 3 & Alan Cox & 1010000 & Linux \\
\hline 4 & Larry Wall & 975000 & Perl \\
\hline 5 & Ask Bjørn Hansen & 716000 & Perl \\
\hline 6 & Guido van Rossum & 574000 & Python \\
\hline 7 & Mark Shuttleworth & 486000 & Ubuntu \\
\hline 8 & Rasmus Lerdorf & 365000 & PHP \\
\hline 9 & Miguel de Icaza & 348000 & GNOME \\
\hline 10 & Jens Axboe & 323000 & Linux \\
\hline 11 & Wietse Venema & 293000 & Postfix \\
\hline 12 & Eric S. Raymond & 287000 & Open Source \\
\hline 13 & Tom Christiansen & 285000 & Perl \\
\hline
\end{tabular}




\begin{tabular}{|c|c|c|c|}
\hline 14 & Bruce Perens & 270000 & Debian \\
\hline 15 & Donald E. Knuth & 252000 & $\mathrm{TeX}$ \\
\hline 16 & Randal L. Schwartz & 252000 & Perl \\
\hline 17 & Jeremy Allison & 247000 & Samba \\
\hline 18 & David Heinemeier Hansson & 244000 & Ruby \\
\hline 19 & Alex Martelli & 231000 & Python \\
\hline 20 & Theo de Raadt & 213000 & OpenBSD \\
\hline 21 & Ian Murdock & 209000 & Debian \\
\hline 22 & Frank Damgaard & 206000 & Linux \\
\hline 23 & Ian Jackson & 202000 & Debian \\
\hline 24 & Peter Toft & 180000 & Linux \\
\hline 25 & Werner Koch & 179000 & GnuPG \\
\hline 26 & Matt Welsh & 168000 & Linux \\
\hline 27 & Brian Behlendorf & 168000 & Apache \\
\hline 28 & Michael K. Johnson & 158000 & Linux \\
\hline 29 & Paul Mackerras & 153000 & Linux \\
\hline 30 & Andrew Tridgell & 144000 & Samba \\
\hline 31 & Eric Allman & 143000 & Sendmail \\
\hline 32 & Jason R. Thorpe & 138000 & NetBSD \\
\hline 33 & Mads Bondo Dydensborg & 132000 & Linux \\
\hline 34 & Roland Mcgrath & 122000 & Glibc \\
\hline 35 & David Axmark & 108000 & MySQL \\
\hline 36 & Dean Gaudet & 106000 & Apache \\
\hline 37 & Jes Sørensen & 105000 & Linux \\
\hline 38 & Hubert Feyrer & 99400 & NetBSD \\
\hline 39 & Poul Henning Kamp & 98800 & FreeBSD \\
\hline 40 & Leslie Lamport & 98200 & LaTeX \\
\hline 41 & Matthias Ettrich & 94000 & $\mathrm{KDE}$ \\
\hline 42 & Manuel Bouyer & 91900 & NetBSD \\
\hline 43 & Henrik Størner & 89900 & Linux \\
\hline
\end{tabular}




\begin{tabular}{|c|c|c|c|}
\hline 44 & Ryan Bloom & 89500 & Apache \\
\hline 45 & Lars Wirzenius & 85200 & Linux \\
\hline 46 & Anton Blanchard & 82900 & Linux \\
\hline 47 & Marc Slemko & 77400 & Apache \\
\hline 48 & Johan Vromans & 74900 & Perl \\
\hline 49 & Bill Stoddard & 74900 & Apache \\
\hline 50 & Jordan K. Hubbard & 73500 & FreeBSD \\
\hline 51 & Jörg Schilling & 68800 & cdrecord \\
\hline 52 & Robin Dunn & 68300 & wxPython \\
\hline 53 & John Ousterhout & 67100 & TCL \\
\hline 54 & Rob Pike & 66300 & Plan 9 \\
\hline 55 & Mitch Kapor & 62900 & Mozilla \\
\hline 56 & Greg Lehey & 62600 & FreeBSD \\
\hline 57 & Roy T. Fielding & 60900 & User \\
\hline 58 & Bob Young & 60800 & Red Hat \\
\hline 59 & Paul Vixie & 60400 & bind \\
\hline 60 & David Brownlee & 59700 & NetBSD \\
\hline 61 & Andrew Eddie & 54400 & Mambo \\
\hline 62 & der Mouse & 53500 & NetBSD \\
\hline 63 & Matthew Green & 51700 & NetBSD \\
\hline 64 & Julian Smart & 51700 & wxWidgets \\
\hline 65 & Charles M. Hannum & 49300 & NetBSD \\
\hline 66 & Ignatios Souvatzis & 48900 & NetBSD \\
\hline 67 & Roy Fielding & 48800 & Apache \\
\hline 68 & Michael Monty Widenius & 46800 & MySQL \\
\hline 69 & Chris G. Demetriou & 46600 & NetBSD \\
\hline 70 & Todd Vierling & 45700 & NetBSD \\
\hline 71 & Bill Studenmund & 44900 & NetBSD \\
\hline 72 & Luke Mewburn & 43000 & NetBSD \\
\hline 73 & Simon Burge & 42800 & NetBSD \\
\hline
\end{tabular}




\begin{tabular}{|c|l|c|l|}
\hline 74 & Perry E. Metzger & 39700 & NetBSD \\
\hline 75 & Daniel J. Bernstein & 39400 & Qmail \\
\hline 76 & Jim Blandy & 39000 & Guile \\
\hline 77 & Wes Hardaker & 32900 & SNMP \\
\hline 78 & Alistair Crooks & 31300 & NetBSD \\
\hline 79 & Daniel Laliberte & 30900 & Hypernews \\
\hline 80 & Jim Winstead & 29400 & Apache \\
\hline 81 & David Kastrup & 29400 & Emacs \\
\hline 82 & Stephen Rothwell & 27800 & APM \\
\hline 83 & Lars Magne Ingebrigtsen & 25200 & Gnus \\
\hline 84 & Dennis Ritchie & 22800 & Plan 9 \\
\hline 85 & Per Abrahamsen & 21000 & Emacs \\
\hline 86 & Jamie Zawinski & 16200 & XEmacs \\
\hline 87 & Michael Elkins & 11400 & Mutt \\
\hline 88 & Hrvoje Niksic & 11100 & Emacs \\
\hline 89 & Jens M Andreasen & 10700 & Linux \\
\hline 90 & Kim F. Storm & 9610 & Emacs \\
\hline 91 & Paul Kinnucan & 894 & JDE \\
\hline 92 & Julian Seward & 609 & Ghc \\
\hline 93 & Steven L. Baur & 595 & XEmacs \\
\hline & & \\
\hline
\end{tabular}


$\stackrel{\infty}{9}$

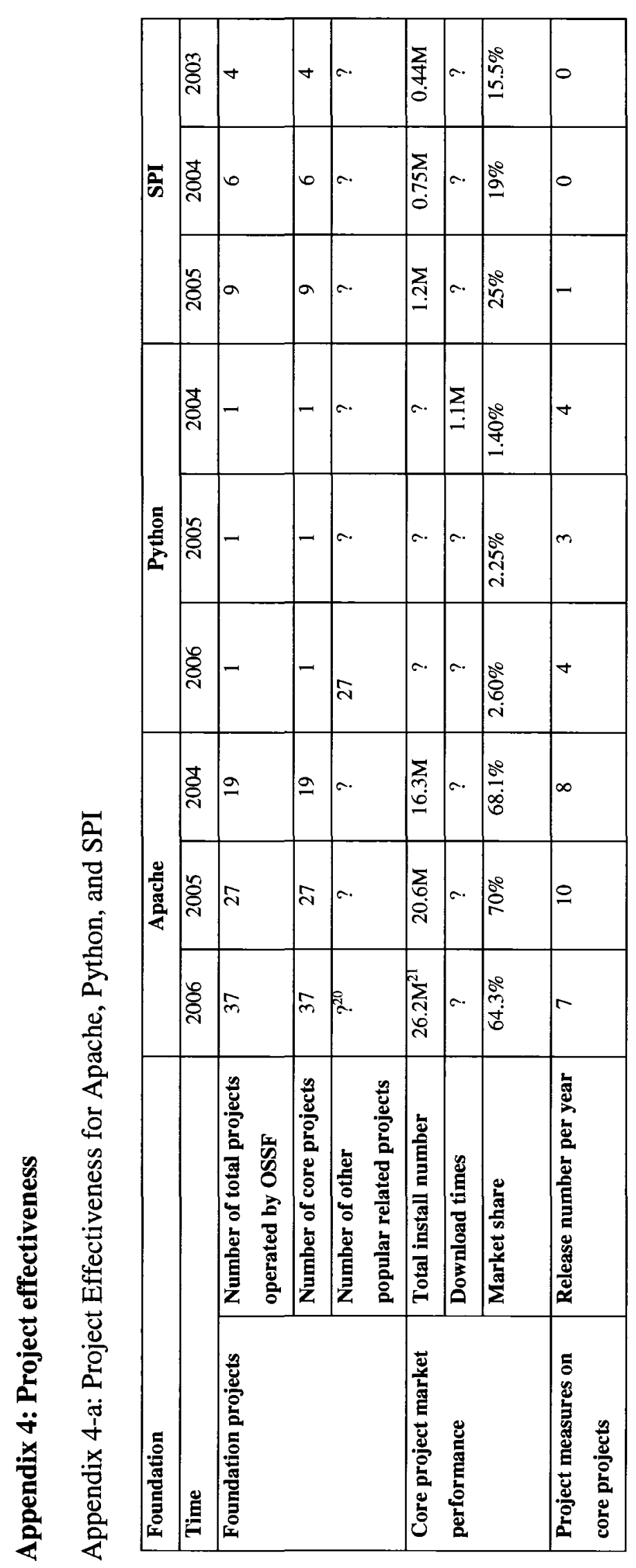

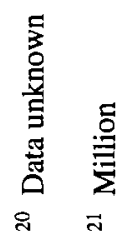


9

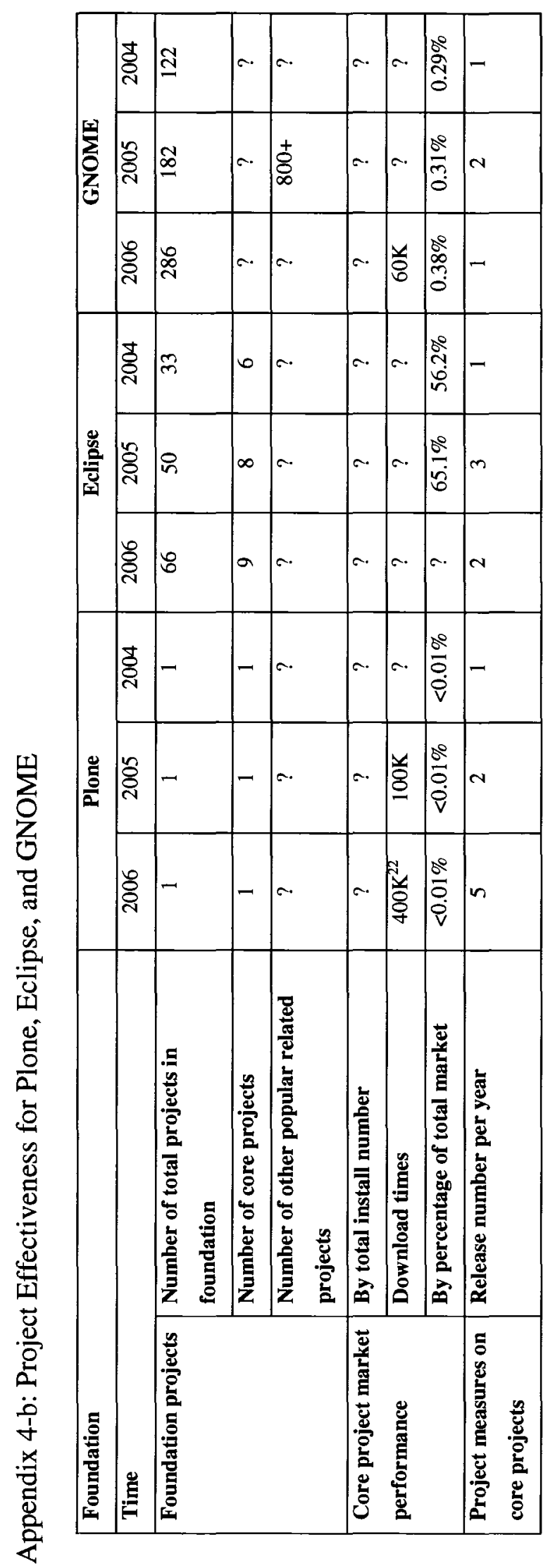


$\cong$

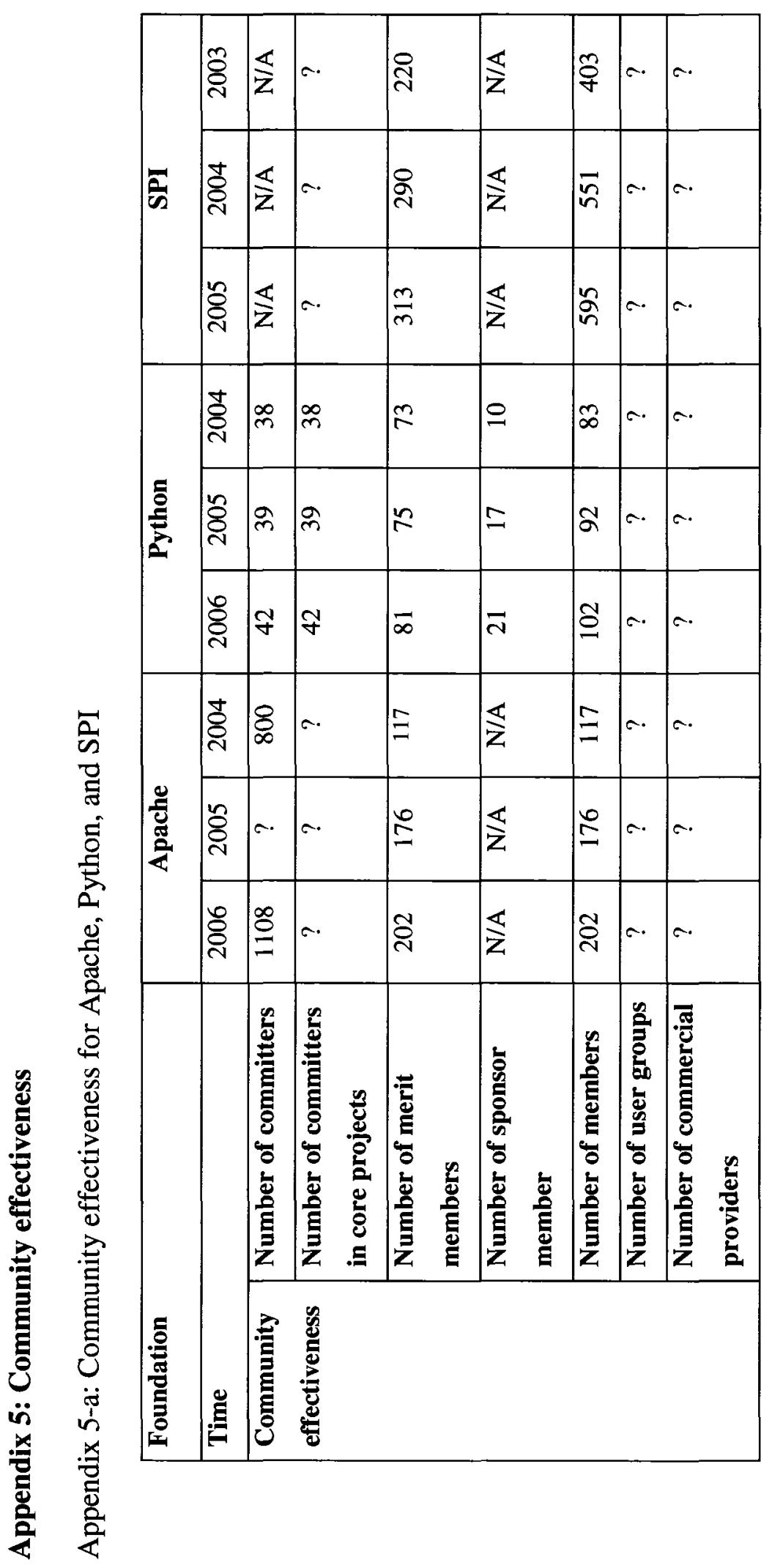


$\Xi$

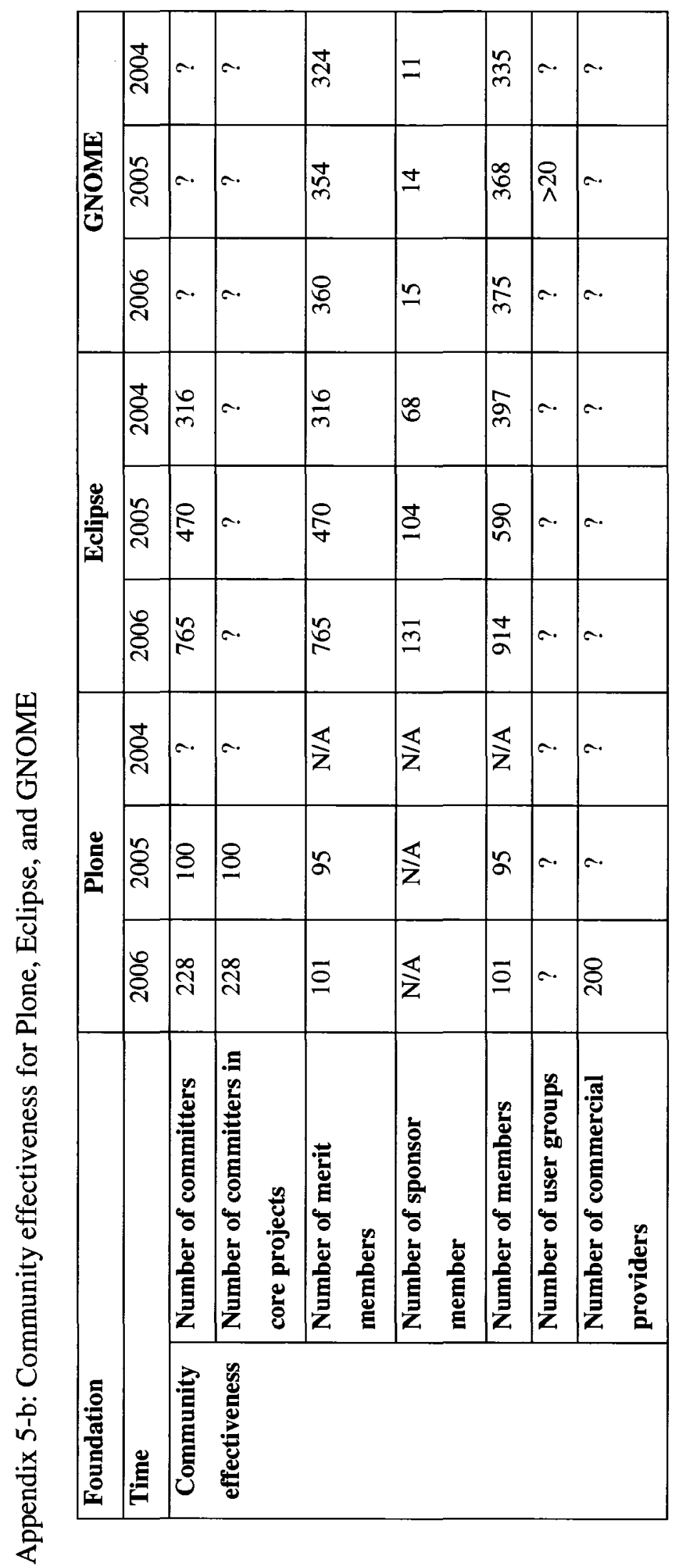




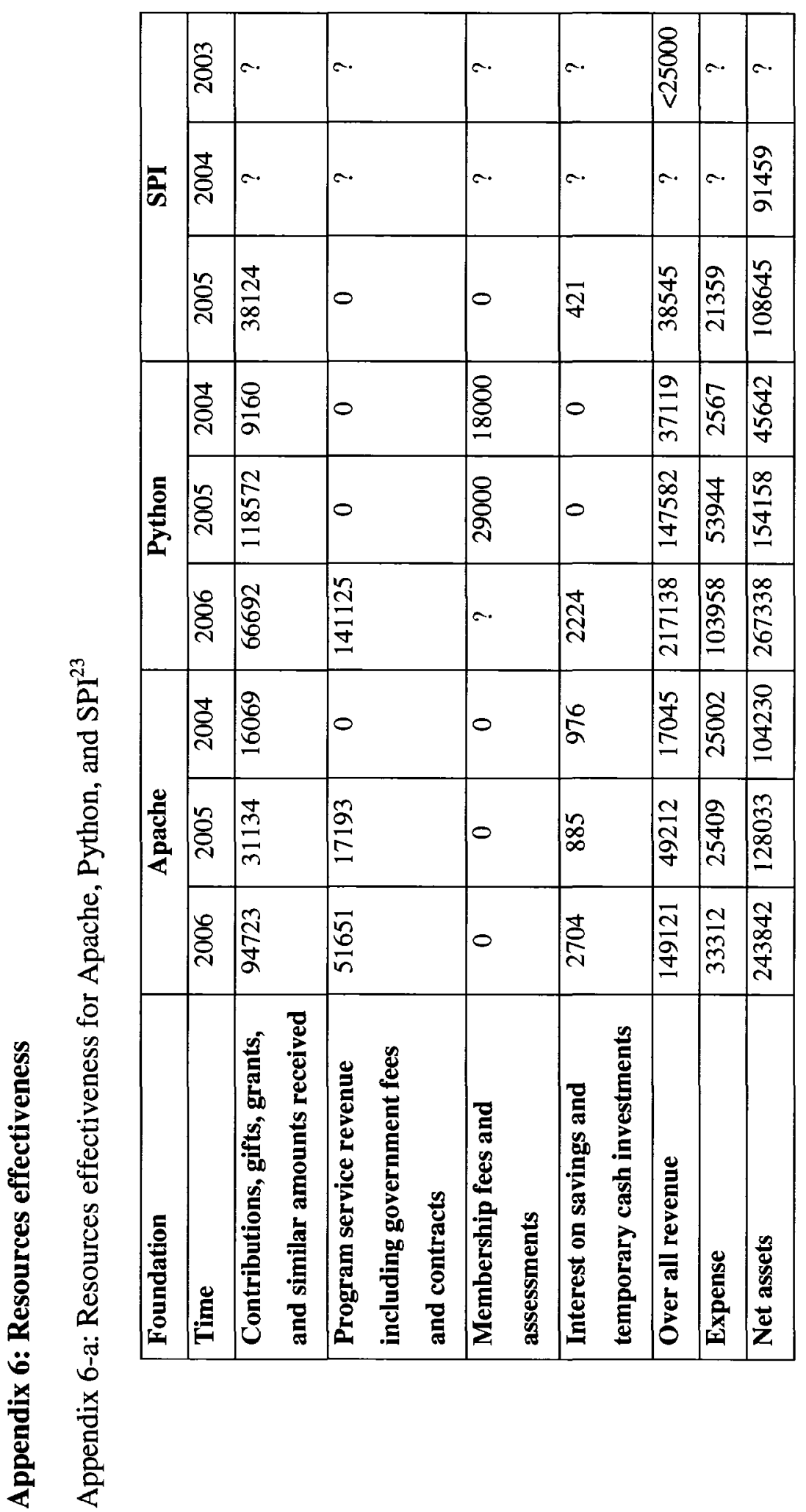




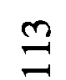

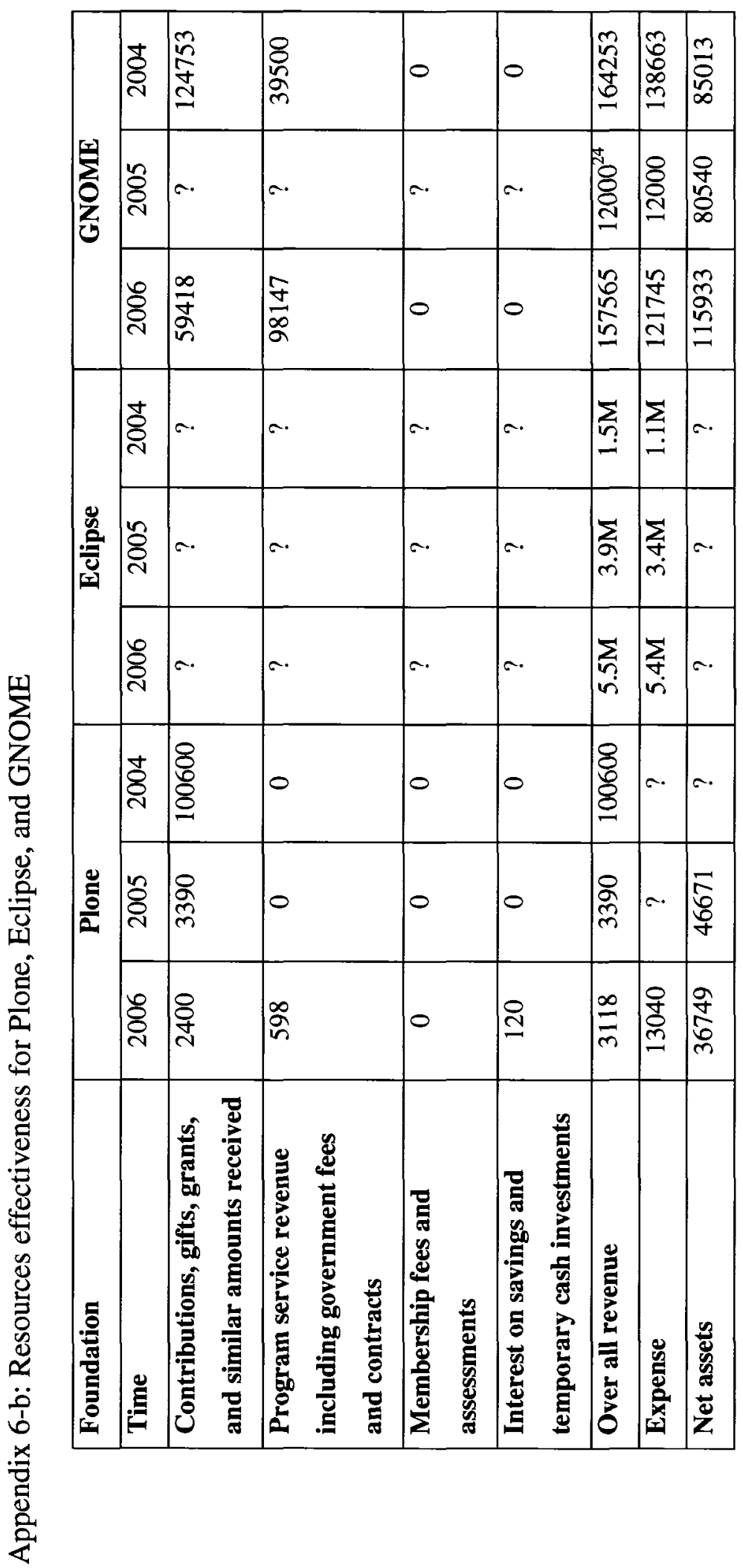

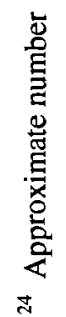

